\title{
Structural Behaviors of Reinforced Concrete Piers Rehabilitated with FRP Wraps
}

\author{
Junsuk Kang \\ Department of Landscape Architecture and Rural Systems Engineering, Seoul National University, Seoul 08826, Republic of Korea \\ Correspondence should be addressed to Junsuk Kang; junkang@snu.ac.kr
}

Received 20 August 2017; Revised 13 October 2017; Accepted 24 October 2017; Published 19 November 2017

Academic Editor: Nobuhiro Kawatsuki

Copyright (C) 2017 Junsuk Kang. This is an open access article distributed under the Creative Commons Attribution License, which permits unrestricted use, distribution, and reproduction in any medium, provided the original work is properly cited.

\begin{abstract}
The use of fiber-reinforced polymer (FRP) wraps to retrofit and strengthen existing structures such as reinforced concrete piers is becoming popular due to the higher tensile strength, durability, and flexibility gained and the method's ease of handling and low installation and maintenance costs. As yet, however, few guidelines have been developed for determining the optimum thicknesses of the FRP wraps applied to external surfaces of concrete or masonry structures. In this study, nonlinear pushover finite element analyses were utilized to analyze the complex structural behaviors of FRP-wrapped reinforced rectangular piers. Design parameters such as pier section sizes, pier heights, pier cap lengths, compressive strengths of concrete, and the thicknesses of the FRP wraps used were thoroughly tested under incremental lateral and vertical loads. The results provide useful guidelines for analyzing and designing appropriate FRP wraps for existing concrete piers.
\end{abstract}

\section{Introduction}

The use of fiber-reinforced polymer (FRP) wraps to retrofit and strengthen existing deteriorating concrete or masonry structures is attractive as these lightweight materials improve tensile strength, durability, and flexibility, are easy to handle, and incur low installation and maintenance costs [1]. FRP materials are thus increasingly being used to enhance or restore the load-carrying capacity, ductility, and seismic resistance of a wide range of structures. A FRP sheet or laminate is composed of uniaxial fibers stacked in various fiber arrangements such as $0^{\circ} / 90^{\circ}$ or $0^{\circ} / 90^{\circ} /+45^{\circ} /-45^{\circ}$ to overcome the anisotropic behavior of uniaxial FRP wraps and embedded in an epoxy resin matrix [1]. A number of different fibers, including carbon, aramid, glass, basalt, or natural fibers can be used. The properties of the resulting FRP wrap can therefore be optimized using various arrangements and materials according to the strength, stiffness, or ductility required by a specific application. The type of structure, for example, whether it consists of beams, columns, and/or slabs, must also be considered.

A great deal of research [2-6] has been done to investigate the benefits to be gained by applying FRP materials to pier structures, but as yet no detailed design guidelines have been developed for the optimum thicknesses of the FRP wraps to be used. There have also been no evaluations reported of the structural effects of FRP wraps for reinforced concrete piers or columns. Although the American Concrete Institute (ACI) [7] has provided some guidelines for noncircular concrete columns, it is not easy to predict the interactions between the piers and pier caps in pier systems using current ACI guidelines. This study therefore focused on the retrofit and rehabilitation of existing reinforced concrete piers using carbon-based FRP wraps. Figure 1 shows how FRP wraps are normally applied to existing reinforced concrete columns $[1,8]$, which is generally done to enhance the shear strength of the structure. This study investigated the effects of FRP wraps on a number of different important structural characteristics, such as stiffness, strength, and ductility. The primary objective of this study was to evaluate the optimum thickness for the FRP wraps and the resulting structural effects for existing rectangular concrete piers. Accurate information on the thickness of the FRP wraps needed for various types and conditions of structures is essential for designers and practitioners when selecting FRP systems whose performance will satisfy their requirements. 


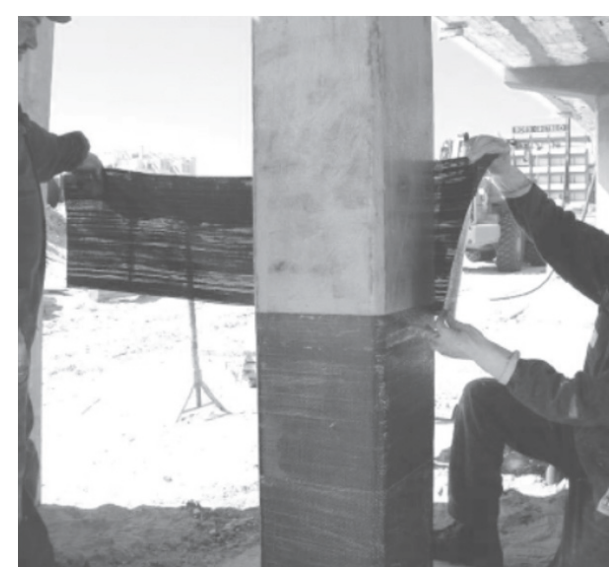

(a) Shear strengthening by FRP wraps [1]

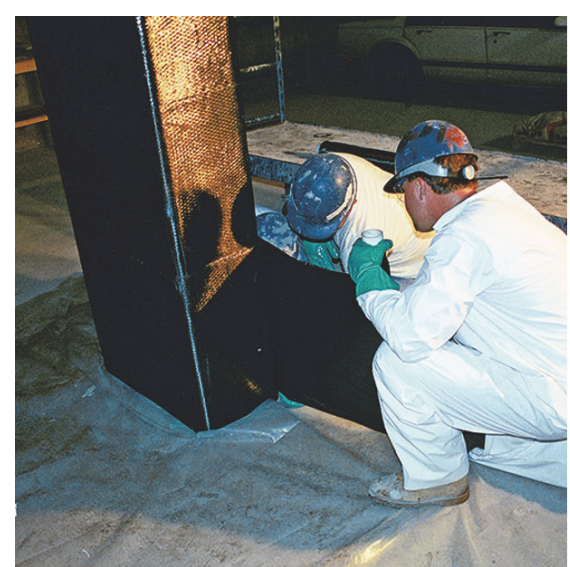

(b) Structural technologies, https://www.vsl.net/ service/strengthening [8]

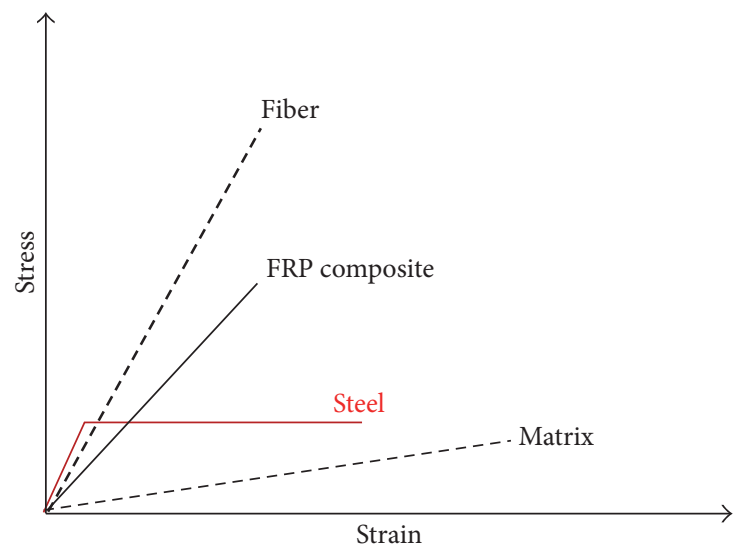

(c) Typical stress-strain curves for fiber, matrix, steel, and FRP composite

FIGURE 1: Application methods and properties of FRP wraps.

\section{Background}

Infrastructure elements across the globe have been deemed structurally deficient in recent years due to deterioration, with some becoming functionally obsolete due to the increased loads they are expected to carry. In the case of degraded bridge structures this can be a costly exercise as it is often necessary for the entire substructure, not just the superstructure, to be demolished and replaced. Given the expense and length of time involved for new construction, attempts are now being made to retrofit and rehabilitate existing substructures, which can be a viable option in the following cases: (1) highway bridges are repurposed to become pedestrian or animal bridges; (2) bridge construction needs to be accelerated; and (3) the demolition of the existing substructure will have a critically adverse impact on the local ecological environment.

The use of FRP materials for retrofitting and strengthening deteriorated concrete structures has become an increasingly attractive proposition due to their superior characteristics. FRP composites are consisted of layers of fibers embedded in a resin matrix: the fibers provide strength and stiffness and the matrix (generally an epoxy resin) protects the fibers from abrasion or damage and transfers stresses between the fibers. Figure 1(c) shows a set of typical stress-strain curves for the fibers and matrix individually and for the resulting FRP composite. As the figure demonstrates, the stress-strain curves for the FRP composite falls between those for the fiber and matrix curves. The properties of FRP composites are affected by the fiber quality, orientation and shape, volume ratio, and manufacturing conditions and FRP products can be produced in the form of plates, sheets, or rods. If done correctly, the application of FRP wraps to existing reinforced concrete columns will increase their strength as well as their ductility by confining the concrete, thus inducing triaxial stress within the concrete structure. The overall effects of adding FRP wraps to columns or piers should, however, be evaluated by considering the structural system as a whole, including both the piers and the pier cap, rather than testing just an isolated column. The complex interactions between the piers and the pier cap associated with various loading and geometry conditions need to be thoroughly investigated to confirm the effectiveness or otherwise of installing FRP wraps. 
TABLE 1: Material properties for FRP wraps [7].

\begin{tabular}{lc}
\hline Thickness per ply & $0.033 \mathrm{~cm}(0.013 \mathrm{in})$. \\
Ultimate tensile strength & $3,792 \mathrm{MPa}(550 \mathrm{ksi})$ \\
Rupture strain & $0.0167 \mathrm{~cm} / \mathrm{cm}$ \\
Modulus of elasticity & $227 \mathrm{GPa}(33,000 \mathrm{ksi})$ \\
Poisson's ratio & 0.3 \\
Coefficient of thermal expansion & $6.500 E-6$ \\
Shear modulus & $87 \mathrm{GPa}(12,692 \mathrm{ksi})$ \\
\hline
\end{tabular}

\section{Analytical Study}

3.1. FRP Materials. The carbon-based FRP materials used in the example given in ACI 440.2R-08 [7] were also utilized in this study; their properties are listed in Table 1. The stacking sequence of each FRP ply is assumed to be balanced, for example, either $0^{\circ} / 90^{\circ}$ or $0^{\circ} / 90^{\circ} /+45^{\circ} /-45^{\circ}$; hence the anisotropic behavior of each FRP ply is assumed to cancel out across each sample and the FRP wraps are considered to be flexible sheets. As the stress-strain curves in Figure 1(c) show, FRP composites have a higher ultimate strength and lower strain at failure than steel.

3.2. Finite Element (FE) Models. The SAP2000 finite element analysis software [9] was used to perform a nonlinear incremental analysis of the structural elements as this software is one of the most used software systems by bridge engineers for nonlinear static analysis of highway bridges [10]. Shatarat et al. [11] evaluated the effects of plastic hinge for four old highway bridges through hinge models and pushover analyses in the SAP 2000. Their studies, however, were limited to flexure dominated conventionally reinforced concrete bridge piers. Kulkarni and Karadi [12] analyzed the existing bridges using nonlinear pushover analysis through the SAP 2000. Their studies considered both vertical and lateral pushover analyses. Kappos et al. [13] performed various pushover analyses such as pushover analysis, modal pushover analysis, and nonlinear time history analysis using the SAP 200 and concluded that all three methods yield similar maximum pier top inelastic displacements. In the SAP 2000 software, the nonlinear structural behavior of structural components for pushover analysis can be simulated through nonlinear predetermined plastic hinge properties according to Caltrans hinge model [14] and FEMA $[15,16]$. Therefore, this study adopted these plastic hinge models through the SAP 2000. In addition, nonlinear material properties were considered for both concrete and FRP material in this study as the failure mechanism of these pier systems is highly affected by the nonlinearity of each structural material [17].

The schematic FE models are shown in Figure 2. The 2dimensional frame system shown in Figure 2(a) represents a typical arrangement of two piers and their associated pier cap. The boundary conditions for the bottoms of piers are assumed to be fixed, and incremental vertical and horizontal loads are applied on the pier-pier cap system separately. Beam elements are used for the piers and pier caps, both of which have square sections, as shown in Figure 2(b). A typical
TABLE 2: Data matrix for pier systems.

\begin{tabular}{|c|c|c|c|}
\hline Type & $\begin{array}{l}W \\
(\mathrm{~m})\end{array}$ & $\begin{array}{l}H \\
(\mathrm{~m})\end{array}$ & $\begin{array}{c}\text { Pier section } \\
(\mathrm{m} \times \mathrm{m})\end{array}$ \\
\hline \multirow{4}{*}{$\begin{array}{l}\text { Slender pier system } \\
(W<H)\end{array}$} & \multirow{4}{*}{6} & \multirow{4}{*}{9} & $0.9 \times 0.9$ \\
\hline & & & $1.2 \times 1.2$ \\
\hline & & & $1.5 \times 1.5$ \\
\hline & & & $1.8 \times 1.8$ \\
\hline \multirow{4}{*}{$\begin{array}{l}\text { Slender pier system } \\
(W<H)\end{array}$} & \multirow{4}{*}{6} & \multirow{4}{*}{12} & $0.9 \times 0.9$ \\
\hline & & & $1.2 \times 1.2$ \\
\hline & & & $1.5 \times 1.5$ \\
\hline & & & $1.8 \times 1.8$ \\
\hline \multirow{4}{*}{$\begin{array}{l}\text { Slender pier system } \\
(W<H)\end{array}$} & \multirow{4}{*}{9} & \multirow{4}{*}{12} & $0.9 \times 0.9$ \\
\hline & & & $1.2 \times 1.2$ \\
\hline & & & $1.5 \times 1.5$ \\
\hline & & & $1.8 \times 1.8$ \\
\hline \multirow{4}{*}{$\begin{array}{l}\text { Wide pier system } \\
(W>H)\end{array}$} & \multirow{4}{*}{9} & \multirow{4}{*}{6} & $0.9 \times 0.9$ \\
\hline & & & $1.2 \times 1.2$ \\
\hline & & & $1.5 \times 1.5$ \\
\hline & & & $1.8 \times 1.8$ \\
\hline \multirow{4}{*}{$\begin{array}{l}\text { Wide pier system } \\
(W>H)\end{array}$} & \multirow{4}{*}{12} & \multirow{4}{*}{6} & $0.9 \times 0.9$ \\
\hline & & & $1.2 \times 1.2$ \\
\hline & & & $1.5 \times 1.5$ \\
\hline & & & $1.8 \times 1.8$ \\
\hline
\end{tabular}

deformed shape for a pier system subjected to a lateral load is shown in Figure 2(c). Note that the FRP wraps shown in Figure 2(b) are applied only to the piers, not the pier cap. The adequate input of nonlinear material properties in the FE analyses is critical to evaluate complex nonlinear structural behaviors of the whole pier systems. Figure 3 shows the nonlinear material properties for the FRP wraps and concrete used in the analysis. The FRP behaviors are assumed to be the same for both tensile and compressive loads, and the compressive and tensile behaviors of concrete are assumed to be as shown in Figure 3(b). The various configurations for pier systems and sections tested are shown in Table 2. Here, a pier system with a pier height, $H$, that is longer than the length of the pier cap, $W$, is categorized as a slender pier system, while a pier system whose pier cap $(W)$ is longer than the height of pier $(H)$ is considered to be a wide pier system. The typical dimensions given for piers, pier cap, and pier sections are adopted from information on bridges in the US state of Georgia and cover the upper and lower boundaries for most pier systems.

3.3. Pushover Analysis. This study adopted nonlinear static pushover analysis to evaluate all the stages of failure mechanism for reinforced concrete piers rehabilitated with FRP wraps. Static pushover analysis is usually used to estimate the structural performance of structures subjected to earthquakes via a static inelastic analysis [9], with the applied incremental lateral loads representing earthquake induced forces. In this study, the incremental loadings were applied 


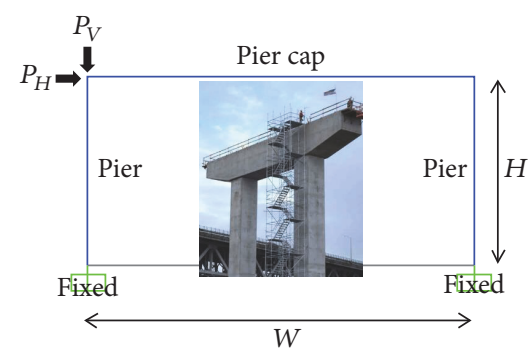

(a) Geometry, loading, and boundary conditions of structure

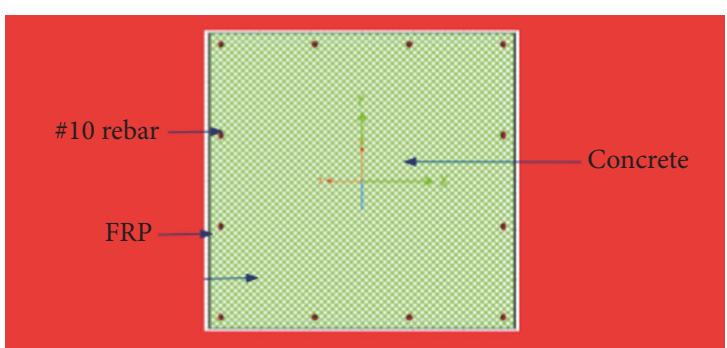

(b) Example of square pier section details

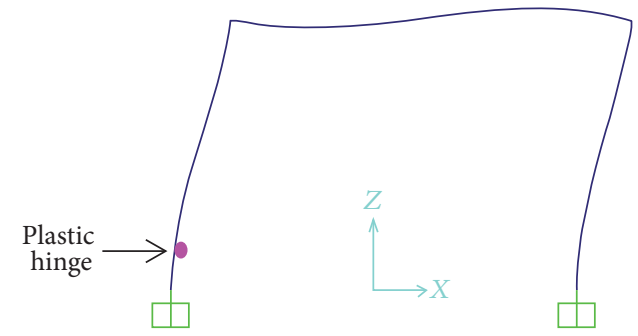

(c) Typical deformed shape under lateral loads

Figure 2: FE model development $\left(P_{H}=\right.$ incremental lateral load; $P_{V}=$ incremental vertical load; $W=$ length of pier cap; and $H=$ height of pier).

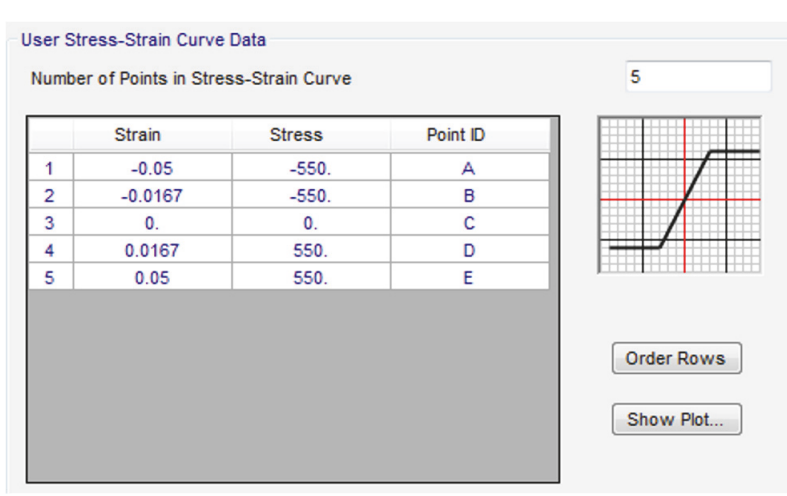

(a) Carbon-based FRP wrap (unit of stress: ksi)

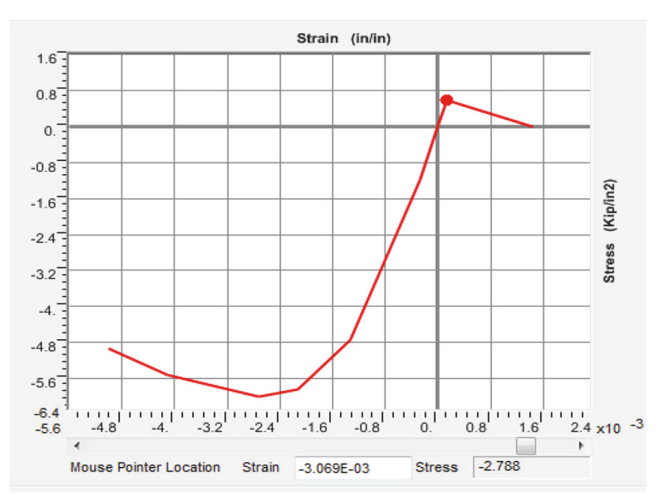

(b) Concrete $\left(f_{c}^{\prime}=6,000 \mathrm{psi}(41.4 \mathrm{MPa})\right)$

FIgURE 3: Stress-strain curve inputs used in the analyses.

at the top of the left hand piers, as shown in Figure 2(a). A plot of the total base shear or reaction versus associated lateral or vertical displacements at the monitoring node is produced where the capacities of the pier systems are represented by load-displacement curves. This analysis therefore examines the ultimate strength, stiffness, and ductility capacity for that specific pier system configuration.

\section{Analytical Results and Discussion}

4.1. Vertical Load Applications. The structural stability of pier systems was investigated by applying incremental vertical loads to the top of the left hand pier as the unsymmetric loading conditions would provide conservative results. All pier sections are square, with dimensions ranging from $0.9 \mathrm{~m}$ by $0.9 \mathrm{~m}$ to $1.8 \mathrm{~m}$ by $1.8 \mathrm{~m}$, as given in Table 2 . The height of the piers $(H)$ and the length of the pier cap $(W)$ are taken to be $6 \mathrm{~m}(19.5 \mathrm{ft})$ and $12 \mathrm{~m}(39 \mathrm{ft})$, respectively. The compressive strengths of the concrete investigated are $21 \mathrm{MPa}$ (3,000 psi), $28 \mathrm{MPa}$ (4,000 psi), $34 \mathrm{MPa}$ (5,000 psi), and $41 \mathrm{MPa}(6,000 \mathrm{psi})$, which cover the most typical compressive strengths of concrete used in the highway bridge piers. The thickness of the carbon FRP wraps is taken to be $3.3 \mathrm{~cm}$ (1.3 in, 100 plies), which is considered to 


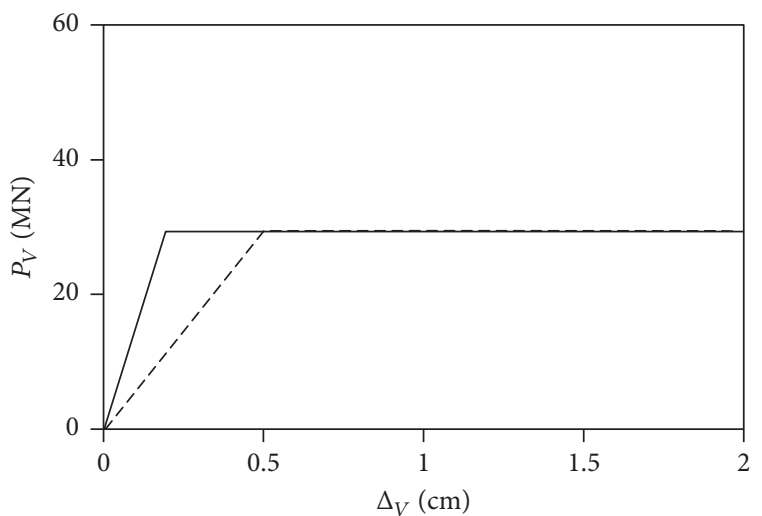

- W/ FRP

- - No FRP

(a) $f_{c}^{\prime}=21 \mathrm{MPa}(3,000 \mathrm{psi})$

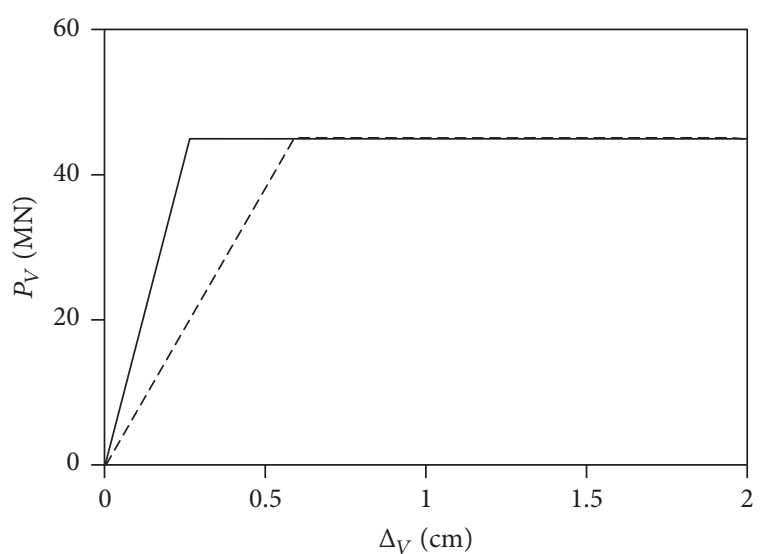

W/ FRP

- - No FRP

(c) $f_{c}^{\prime}=34 \mathrm{MPa}(5,000 \mathrm{psi})$

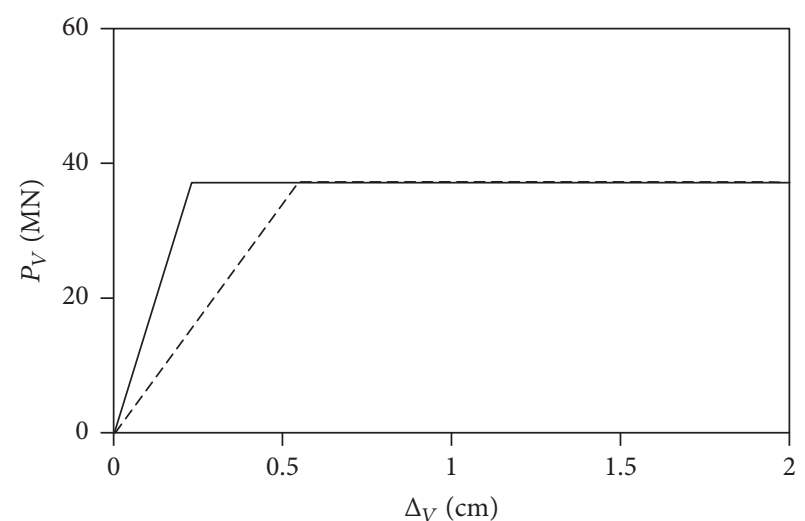

$\mathrm{W} / \mathrm{FRP}$

— W/ FRP

(b) $f_{c}^{\prime}=28 \mathrm{MPa}(4,000 \mathrm{psi})$

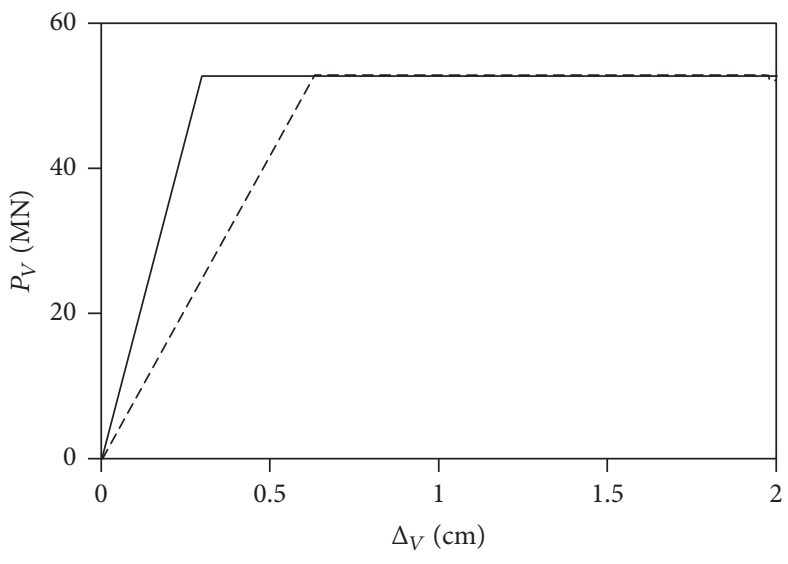

W/ FRP

- - No FRP

(d) $f_{c}^{\prime}=41 \mathrm{MPa}(6,000 \mathrm{psi})$

FIGURE 4: Pier section $(0.9 \mathrm{~m}$ by $0.9 \mathrm{~m}$ ) subjected to vertical loads (thickness of FRP wrap $=3.3 \mathrm{~cm}$ ).

be relatively thick. Therefore, the ultimate effects of FRP wraps for the strength, stiffness, and deformation capacities could be evaluated through this study. The vertical loaddisplacement history can then be plotted to evaluate the pier systems' strength, stiffness, and deformation capacities. Figure 4 shows the structural performance of a pier system composed of $0.9 \mathrm{~m}$ by $0.9 \mathrm{~m}$ piers subjected to incremental vertical loads. The piers wrapped with FRP laminates are compared to those without FRP sheets. As shown in Figure 4, the ultimate strengths of the pier systems remain the same when the piers are rehabilitated with FRP wraps, and this trend is consistent across all the compressive loads tested, which indicates that the thick FRP wraps did not increase the compressive ultimate strengths of the pier system. However, the stiffness, which is defined as the slope in the linear region of the force-displacement response, approximately doubles with the FRP applications in all cases. As long as the load demand remains the same for the intended use of the pier system, it may not be necessary to increase its ultimate strength. The increased stiffness will enhance the structural stability of the system, which may well coincide with the desired benefit to be gained via the FRP wrap application.

For systems with larger pier cross-sections, the data presented in Figures 5-7 confirm that the ultimate strengths of the pier systems do not change with the installation of the FRP wraps. Interestingly, the stiffness of the system approximately doubles in every case except the largest pier section, $1.8 \mathrm{~m}$ by $1.8 \mathrm{~m}$, which showed only a $50 \%$ increase compared to the pier without FRP wraps.

4.2. Lateral Load Applications for Slender Pier Systems. Following the same procedure as that described above for vertical load cases, models were designed and subjected to a lateral load. Due to the fact that lateral loads are highly important for a bridge's performance, a closer look at the effect of different FRP properties was carried out, focusing specifically on the thickness, layering, and material used. 


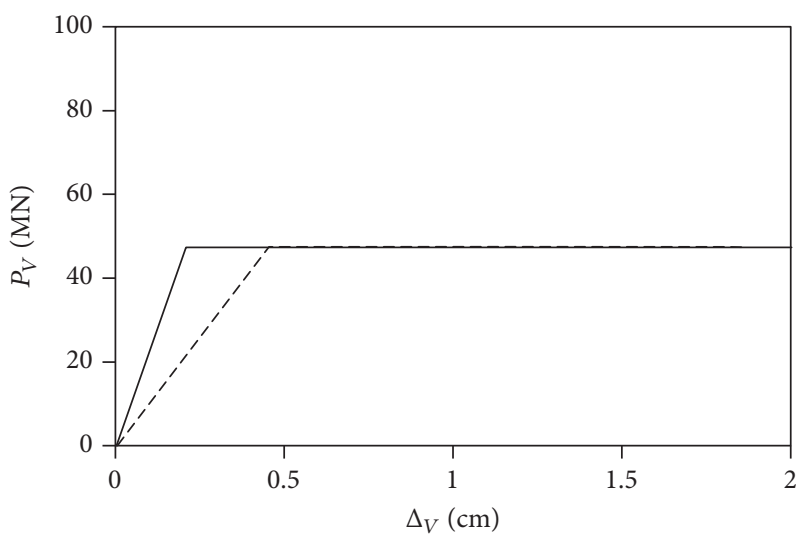

-- No FRP

(a) $f_{c}^{\prime}=21 \mathrm{MPa}(3,000 \mathrm{psi})$

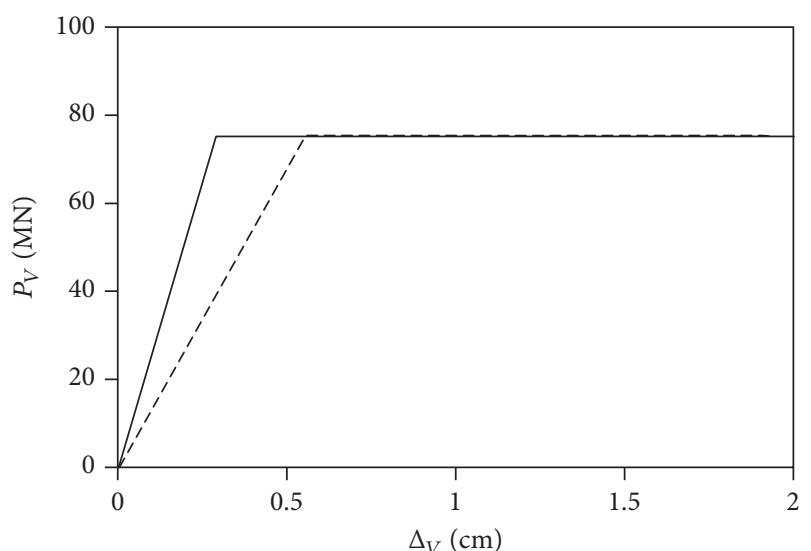

- W/ FRP
-- No FRP

(c) $f_{c}^{\prime}=34 \mathrm{MPa}(5,000 \mathrm{psi})$

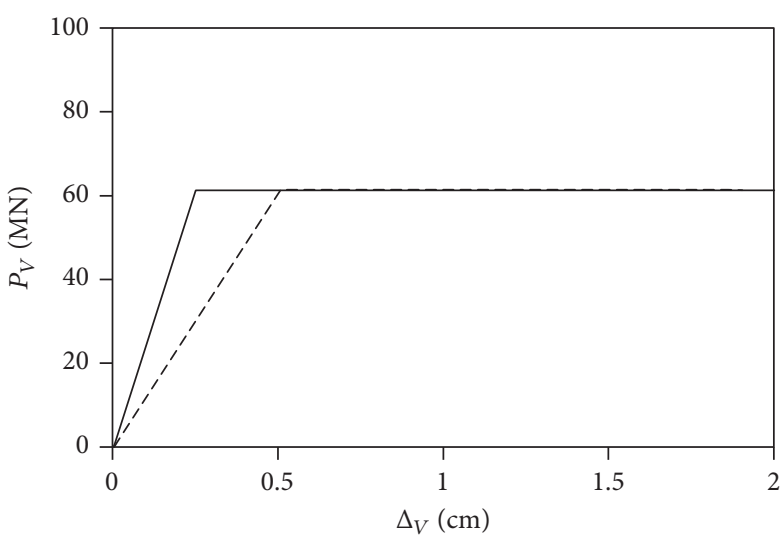

W/ FRP

-- No FRP

(b) $f_{c}^{\prime}=28 \mathrm{MPa}(4,000 \mathrm{psi})$

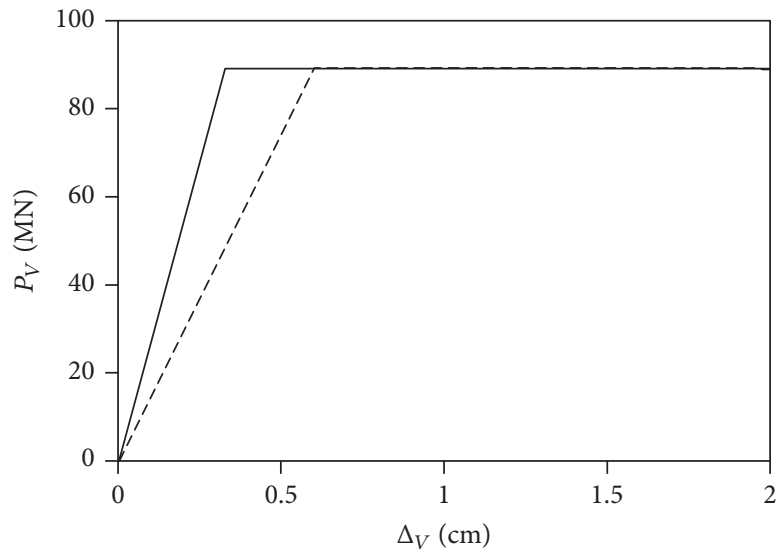

- W/ FRP
(d) $f_{c}^{\prime}=41 \mathrm{MPa}(6,000 \mathrm{psi})$

Figure 5: Pier section $(1.2 \mathrm{~m}$ by $1.2 \mathrm{~m}$ ) subjected to vertical loads (thickness of FRP wrap $=3.3 \mathrm{~cm}$ ).

The incremental lateral loads were applied at the top of the left hand piers to evaluate the expected performance of the slender pier systems. As for the vertical loading case, lateral load-displacement curves were plotted to identify the ultimate strengths, stiffness, and deformation capacity of the slender pier systems.

Figure 8 shows the effect of varying the FRP wrap thickness on the structural performance of a slender pier system with $W=6 \mathrm{~m}$ and $H=9 \mathrm{~m}$. Two pier sections, $0.9 \mathrm{~m}$ by $0.9 \mathrm{~m}$ and $1.2 \mathrm{~m}$ by $1.2 \mathrm{~m}$, were investigated for FRP thicknesses ranging from zero to $6.6 \mathrm{~cm}$. As shown in Figures $8(\mathrm{a})$ and $8(\mathrm{~b})$, both the stiffness and the ultimate strengths of the slender pier systems increased with the addition of FRP wraps. In particular, the FRP wraps with thicknesses greater than $3.3 \mathrm{~cm}$ clearly enhanced the stiffness and ultimate strengths of the system as a whole. Similar trends were shown in the other two slender systems tested: namely, $W=6 \mathrm{~m}$ and $H=12 \mathrm{~m}$ (Figure 9) and $W=9 \mathrm{~m}$ and $H=12 \mathrm{~m}$
(Figure 10). The compressive strength used for the curves shown in Figures 8-10 was $41 \mathrm{MPa}(6,000 \mathrm{psi})$.

4.3. Lateral Load Applications for Wide Pier Systems. Wide pier systems with $W$ larger than $H$ were also investigated for various thicknesses of FRP wraps. As shown in Figure 11, the stiffness of the system was again enhanced by the addition of the FRP wraps. The ultimate strengths of the wide pier system having $W=9 \mathrm{~m}$ and $H=6 \mathrm{~m}$ increased considerably, although some cases did not achieve convergence due to the errors. The ultimate strengths of the wide pier system with a pier section of $1.2 \mathrm{~m}$ by $1.2 \mathrm{~m}$ (Figure 12) were disproportionally increased relative to the thicknesses of the FRP wraps applied. The largest wide pier section tested $(1.5 \mathrm{~m}$ by $1.5 \mathrm{~m})$ exhibited only an insignificant effect on the ultimate strength except for the thickest FRP tested, $6.6 \mathrm{~cm}$. Overall, a wide pier system with an intermediate section size of the order of $1.2 \mathrm{~m}$ by $1.2 \mathrm{~m}$ is likely to benefit most from rehabilitation with FRP 


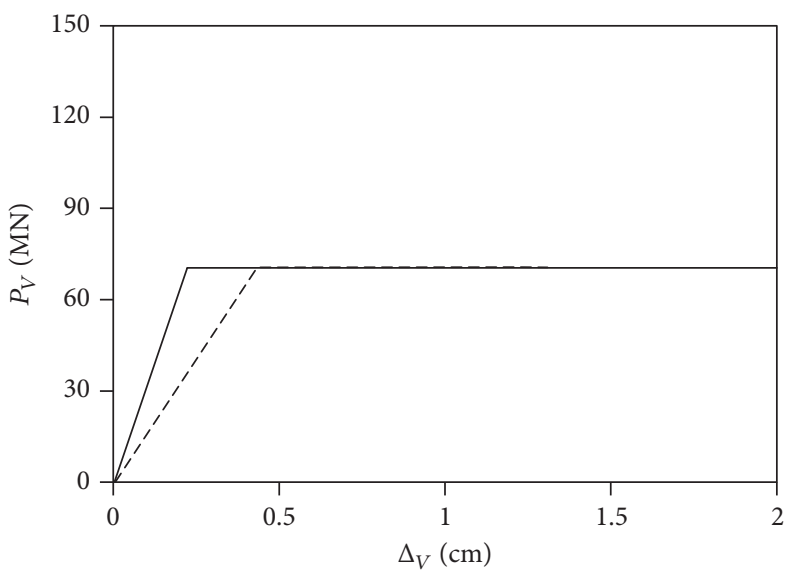

W/ FRP

-- No FRP

(a) $f_{c}^{\prime}=21 \mathrm{MPa}(3,000 \mathrm{psi})$

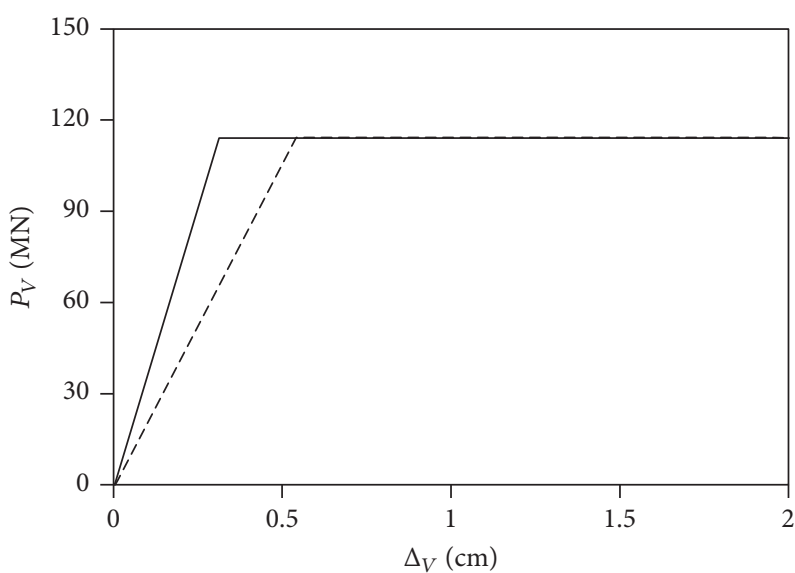

W/ FRP

- - No FRP

(c) $f_{c}^{\prime}=34 \mathrm{MPa}(5,000 \mathrm{psi})$

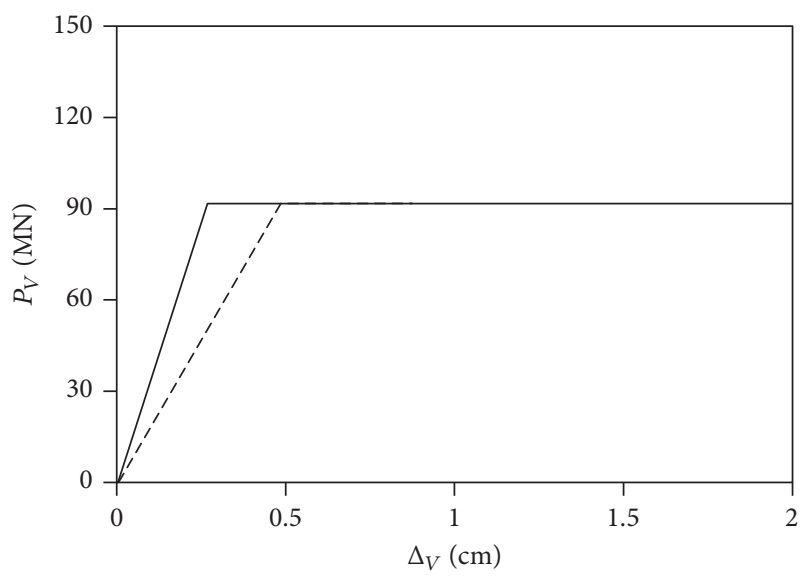

W/ FRP

- - No FRP

(b) $f_{c}^{\prime}=28 \mathrm{MPa}(4,000 \mathrm{psi})$

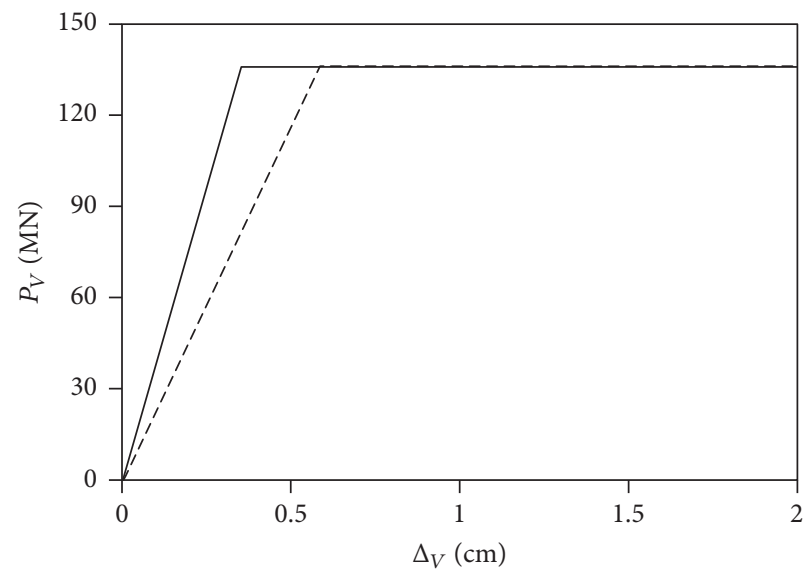

W/ FRP

- - No FRP

(d) $f_{c}^{\prime}=41 \mathrm{MPa}(6,000 \mathrm{psi})$

FIgURE 6: Pier section $(1.5 \mathrm{~m}$ by $1.5 \mathrm{~m}$ ) subjected to vertical loads (thickness of FRP wrap $=3.3 \mathrm{~cm}$ ).

wraps, especially compared to the slender pier systems, where the benefits gained were less obvious.

4.4. Summary of Structural Effects of FRP Wraps. The structural effects of the FRP wraps for the pier systems subjected to incremental lateral loads are summarized in Figure 13 for a pier with a section of $0.9 \mathrm{~m}$ by $0.9 \mathrm{~m}$, which builds on the insights provided by the data presented in Figures 8-12 for all the pier section sizes. The yield points are unclear, with some cases exhibiting multiple yield points, so as defined in Figure 13(a), the stiffness, 1st yield point, 2nd yield point, and ultimate strength are evaluated separately to provide indepth analyses of the structural effects of applying FRP wraps to the pier systems. As shown in Figure 13(b), the wide pier systems are affected more strongly by the addition of FRP wraps than the slender pier systems. However, the 1st and 2nd yield strengths of the pier systems do not change significantly even as the thickness of the FRP wraps increases. Examining the ultimate strengths shown in Figure 13(e), the wider pier system is the only one strongly affected by the FRP thickness.

\section{Simplified $P-M$ Interaction Diagrams}

5.1. ACI Procedures. The ACI provides general guidelines for the analysis and design of reinforced concrete column with FRP wraps surrounding each member's cross-sectional area [7]. According to their recommended procedure, the axial and bending behaviors before and after rehabilitation should be analyzed by calculating the interaction diagrams prior to the addition of FRP and afterwards, then comparing the results.

$P-M$ interaction diagrams are constructed based on the principles of equilibrium and strain compatibility of conventional reinforced concrete columns, considering the stressstrain relationship for FRP-wrapped reinforced concrete [18]. 

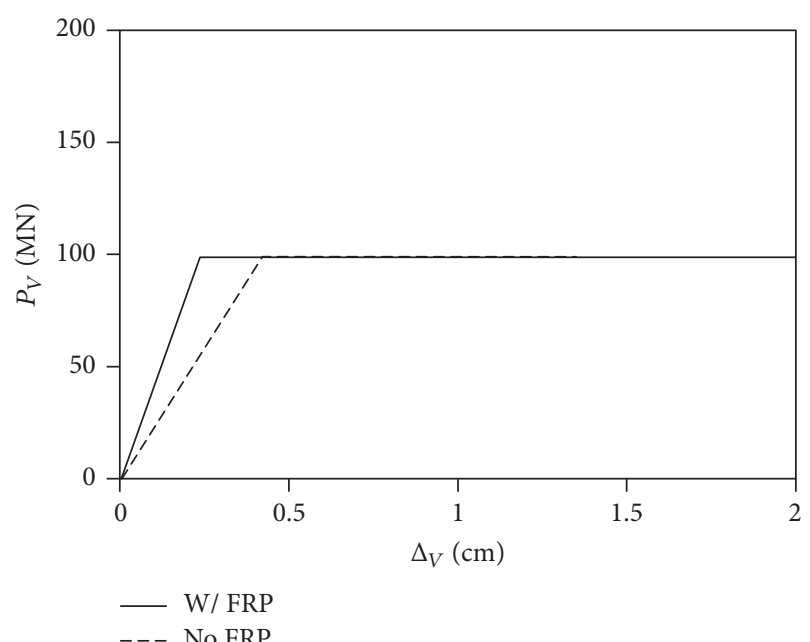

(a) $f_{c}^{\prime}=21 \mathrm{MPa}(3,000 \mathrm{psi})$

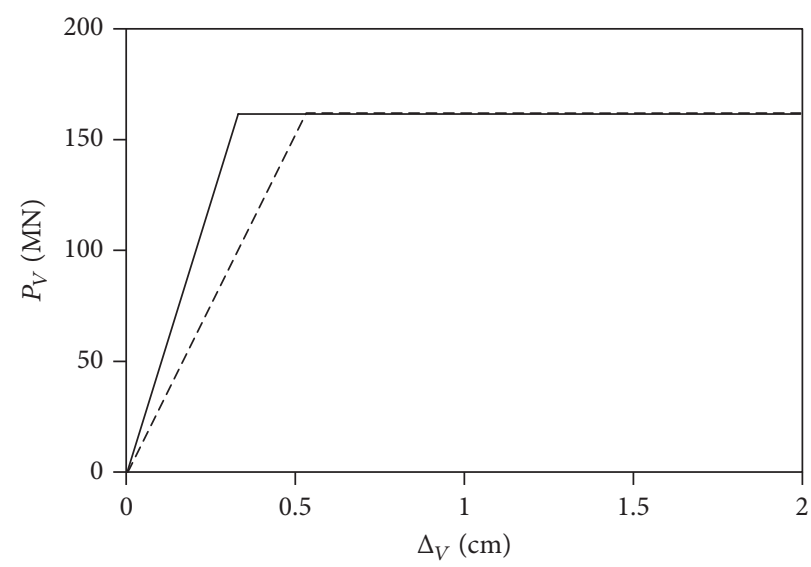

W/ FRP

- - - No FRP

(c) $f_{c}^{\prime}=34 \mathrm{MPa}(5,000 \mathrm{psi})$

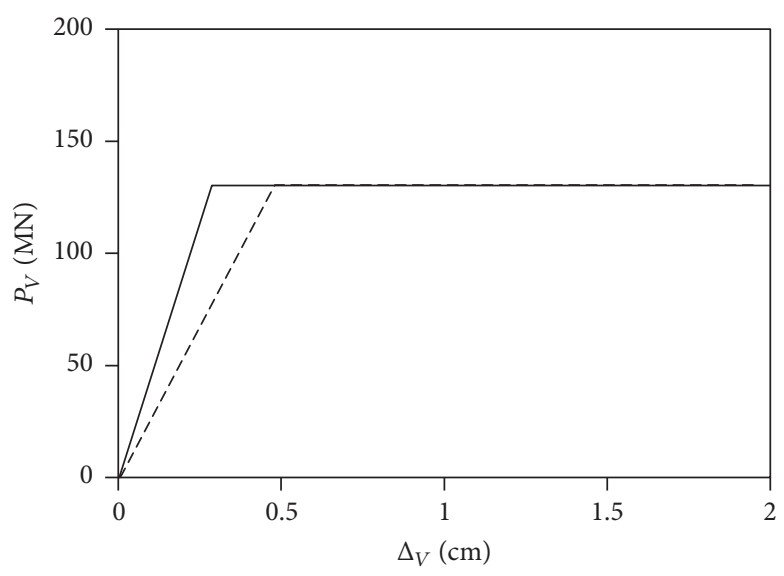

W/ FRP

- - No FRP

(b) $f_{c}^{\prime}=28 \mathrm{MPa}(4,000 \mathrm{psi})$

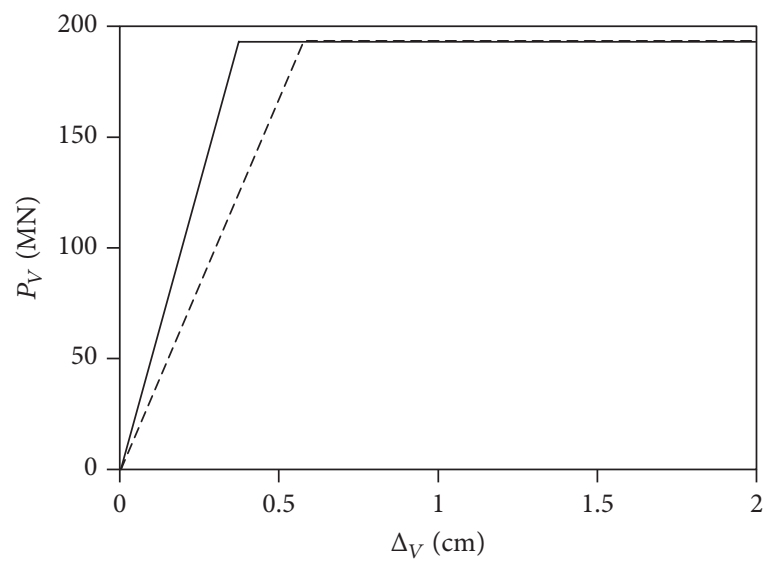

W/ FRP

- - No FRP

(d) $f_{c}^{\prime}=41 \mathrm{MPa}(6,000 \mathrm{psi})$

FIgURE 7: Pier section ( $1.8 \mathrm{~m}$ by $1.8 \mathrm{~m}$ ) subjected to vertical loads (thickness of FRP wrap $=3.3 \mathrm{~cm}$ ).

They can be reduced to two bilinear curves passing through the following three points [7]:

(i) Point A (pure compression) at a uniform axial compressive strain of confined concrete

(ii) Point B with a strain distribution corresponding to zero strain

(iii) Point $\mathrm{C}$ with a strain distribution corresponding to balanced failure, with a maximum compressive strain and a yielding tensile strain

For FRP-wrapped concrete with existing steel-tie reinforcement, the values of $\phi P_{n(\mathrm{~A})}$ corresponding to Point $\mathrm{A}$ are as follows:

$$
\phi P_{n(\mathrm{~A})}=0.8 \phi\left(0.85 f_{c c}^{\prime}\left(A_{g}-A_{s t}\right)+f_{y} A_{s t}\right) .
$$

The coordinates of Points B and C can be calculated as

$$
\begin{aligned}
& \phi P_{n(\mathrm{~B}, \mathrm{C})}=\phi\left[\left(A\left(y_{t}\right)^{3}+B\left(y_{t}\right)^{2}+C\left(y_{t}\right)+D\right)\right. \\
& \left.\quad+\sum A_{s i} f_{s i}\right] \\
& \phi M_{n(\mathrm{~B}, \mathrm{C})} \\
& \quad=\phi\left[\left(E\left(y_{t}\right)^{4}+F\left(y_{t}\right)^{3}+G\left(y_{t}\right)^{2}+H\left(y_{t}\right)+I\right)\right. \\
& \left.\quad+\sum A_{s i} f_{s i} d_{i}\right] .
\end{aligned}
$$

The coefficients $A, B, C, D, E, F, G, H$, and $I$ in these equations can be calculated from ACI 440.2R's [7, Eq. (D-3)]. Design examples reflecting the recommended ACI procedures are presented in the following section.

The primary objective of presenting these ACI procedures and design examples here is to highlight the differences 


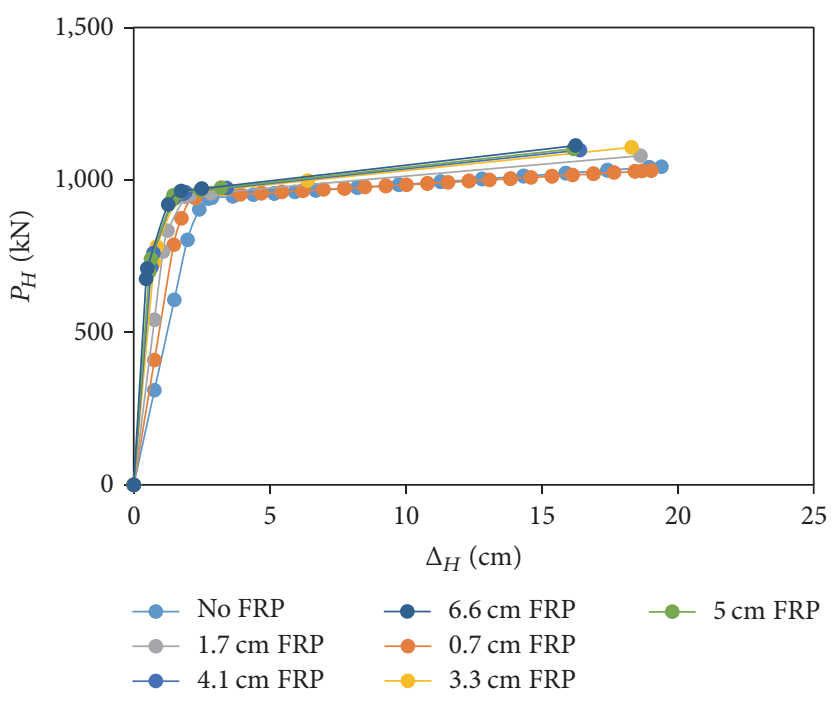

(a) Pier section: $0.9 \mathrm{~m}$ by $0.9 \mathrm{~m}$

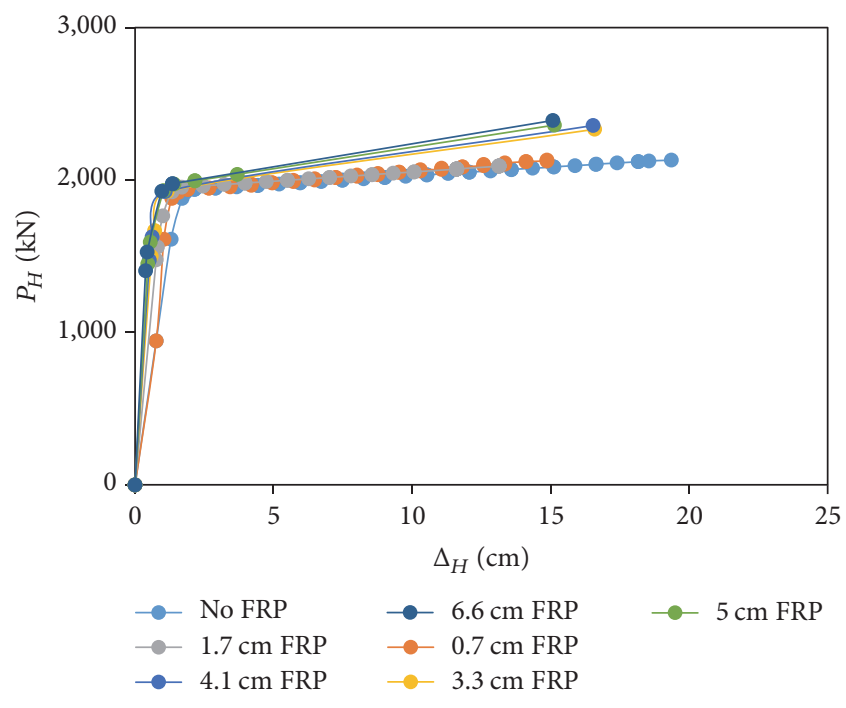

(b) Pier section: $1.2 \mathrm{~m}$ by $1.2 \mathrm{~m}$

Figure 8: Slender pier system with $W=6 \mathrm{~m}$ and $H=9 \mathrm{~m}\left(f_{c}^{\prime}=41 \mathrm{MPa}\right)$.

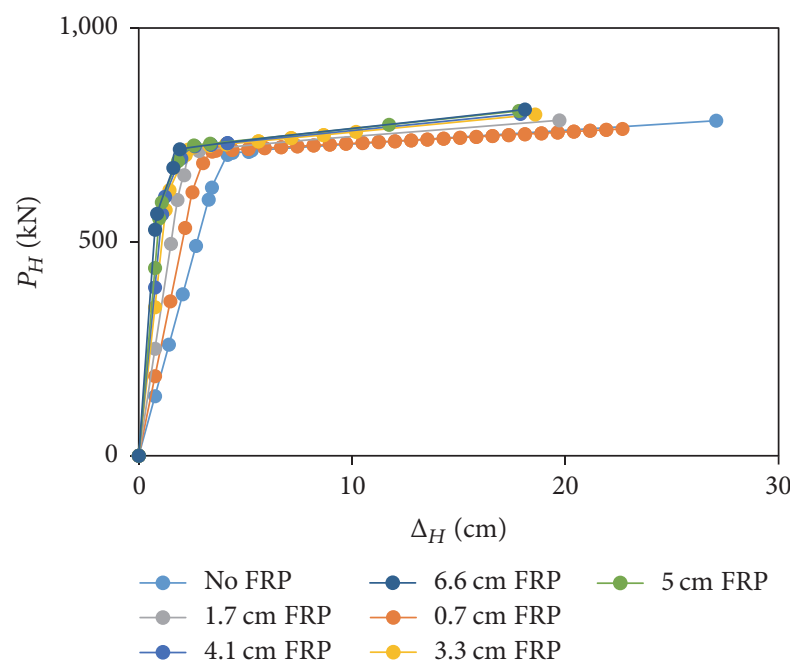

(a) Pier section: $0.9 \mathrm{~m}$ by $0.9 \mathrm{~m}$

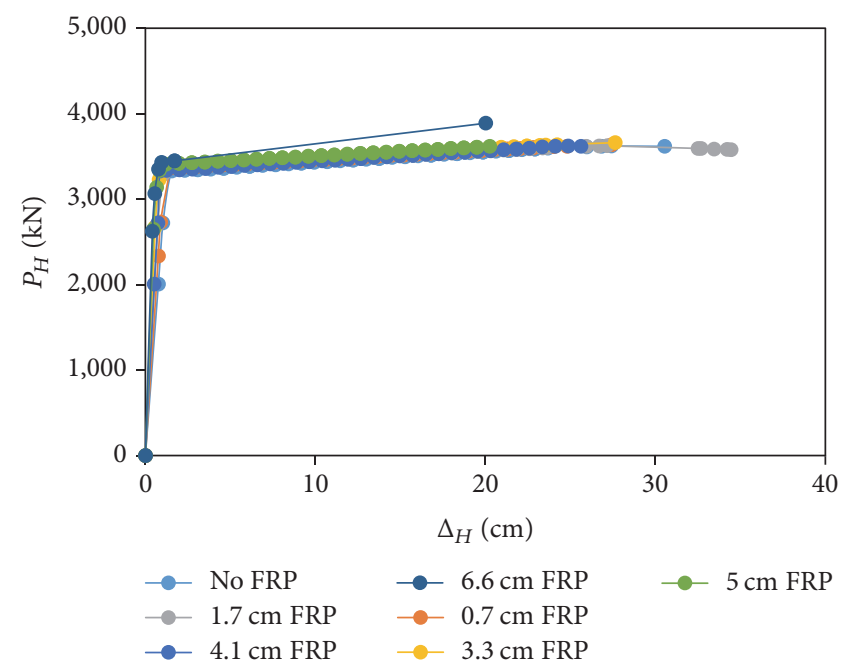

(b) Pier section: $1.8 \mathrm{~m}$ by $1.8 \mathrm{~m}$

FIGURE 9: Slender pier system with $W=6 \mathrm{~m}$ and $H=12 \mathrm{~m}\left(f_{c}^{\prime}=41 \mathrm{MPa}\right)$.

between theoretical approaches that simply consider isolated column members and finite element approaches that consider entire systems and include both piers and pier caps.

5.2. Design Examples. Noncircular reinforced concrete columns with square cross-sections with dimensions of either $0.3 \mathrm{~m}$ by $0.3 \mathrm{~m}$ or $0.6 \mathrm{~m}$ by $0.6 \mathrm{~m}$ containing \#10 rebar were selected to examine the contribution of FRP wrap applications in axial and bending performances in different situation. The ACI procedures were programmed using Excel to develop simplified $P-M$ interaction diagrams for various compressive strengths of concrete, numbers of rebar, and numbers of FRP plies. Figure 14 shows simplified $P-M$ interaction diagrams for rectangular reinforced concrete columns both with and without FRP of various types. Note that the tensile strength of concrete is neglected in these diagrams. The design parameters considered in the analyses are the size of the pier section and the variables listed above, namely, the compressive strength of the concrete, amount of rebar used, and the number of FRP plies.

Figure 14 shows the strength enhancements due to the inclusion of the FRP wraps in the compression-controlled zone. The piers with the larger section of $0.6 \mathrm{~m}$ by $0.6 \mathrm{~m}$ (Figures 14(a) and 14(b)) showed significantly enhanced strengths compared to the smaller $0.3 \mathrm{~m}$ by $0.3 \mathrm{~m}$ piers (Figures 14(c) and 14(d)). 


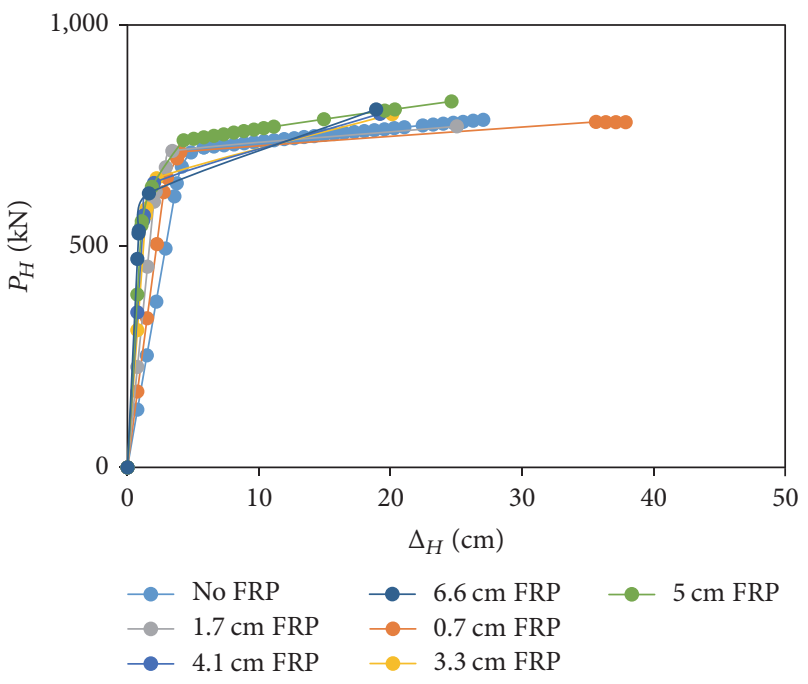

(a) Pier section: $0.9 \mathrm{~m}$ by $0.9 \mathrm{~m}$

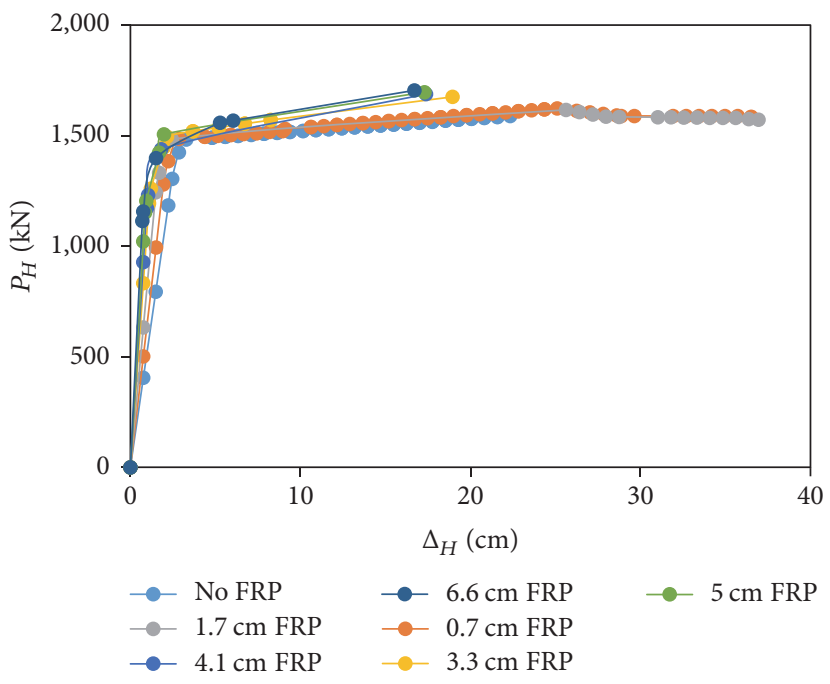

(b) Pier section: $1.2 \mathrm{~m}$ by $1.2 \mathrm{~m}$

FIgURE 10: Slender pier system with $W=9 \mathrm{~m}$ and $H=12 \mathrm{~m}\left(f_{c}^{\prime}=41 \mathrm{MPa}\right)$.

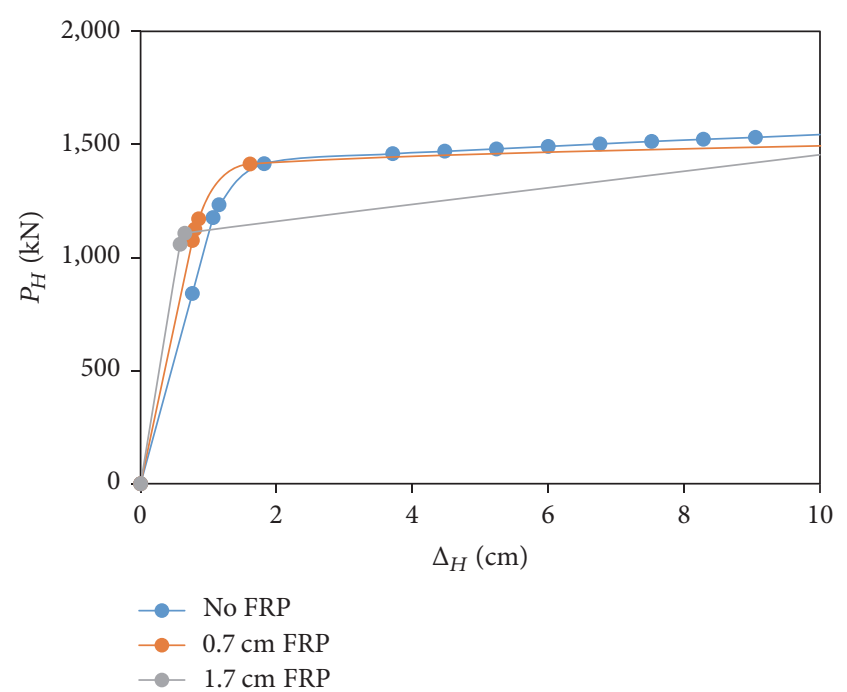

(a) Pier section: $0.9 \mathrm{~m}$ by $0.9 \mathrm{~m}$

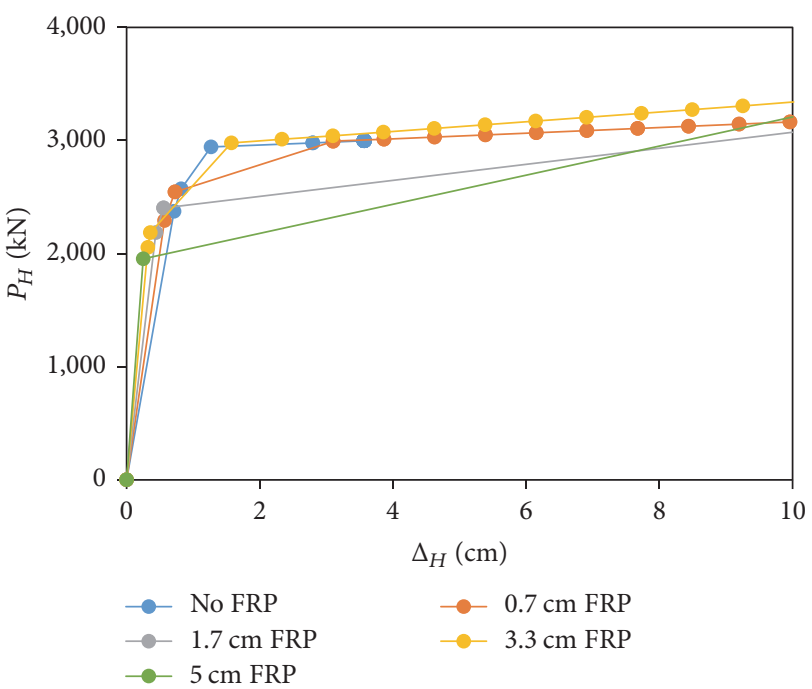

(b) Pier section: $1.2 \mathrm{~m}$ by $1.2 \mathrm{~m}$

FIgURE 11: Wide pier system with $W=9 \mathrm{~m}$ and $H=6 \mathrm{~m}\left(f_{c}^{\prime}=41 \mathrm{MPa}\right)$.

\section{Conclusions}

The analytical study presented here compared pier systems composed of FRP-wrapped square reinforced concrete columns topped by pier caps to evaluate the structural effects induced by the application of the FRP materials. A nonlinear pushover analysis was implemented in conjunction with FE methods; ACI procedures and examples were also presented for comparison. Various configurations of the pier systems were considered to cover most practical cases. Vertical and horizontal load-displacement curves were produced to estimate the ultimate strength, stiffness, yield strength, and deformation capacity of the resulting pier systems. The following conclusions can be drawn from the results of this analysis.

(1) The FE models developed for this study successfully evaluated the complex interactions between piers and pier caps associated with the addition of the FRP wraps, overcoming the limitations of existing theoretical approaches. The elastic, yield, ultimate, 


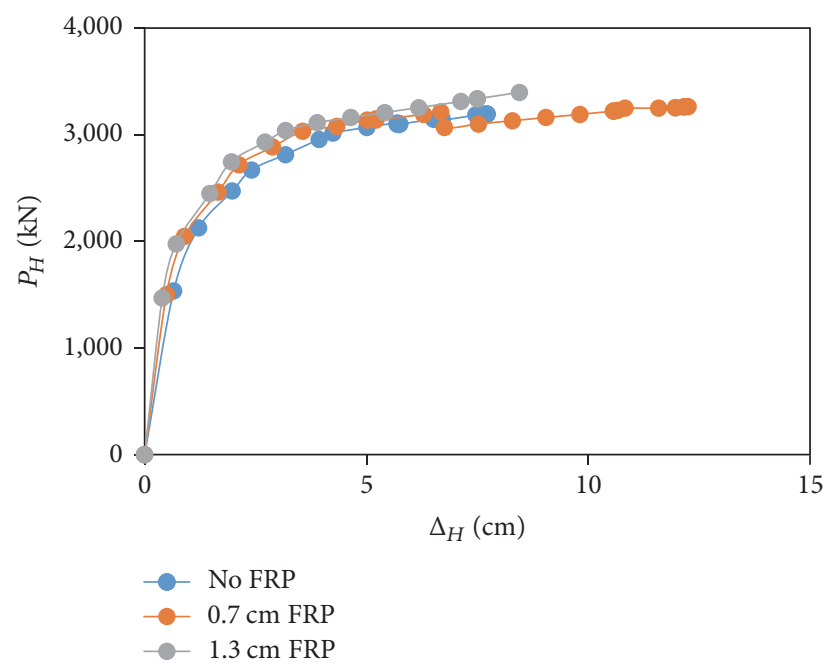

(a) Pier section: $0.9 \mathrm{~m}$ by $0.9 \mathrm{~m}$

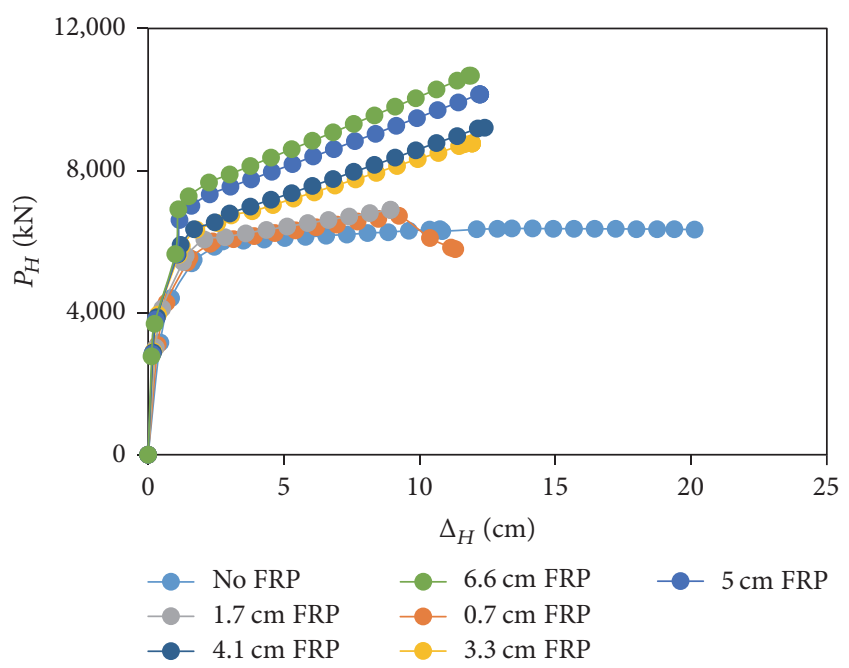

(b) Pier section: $1.2 \mathrm{~m}$ by $1.2 \mathrm{~m}$

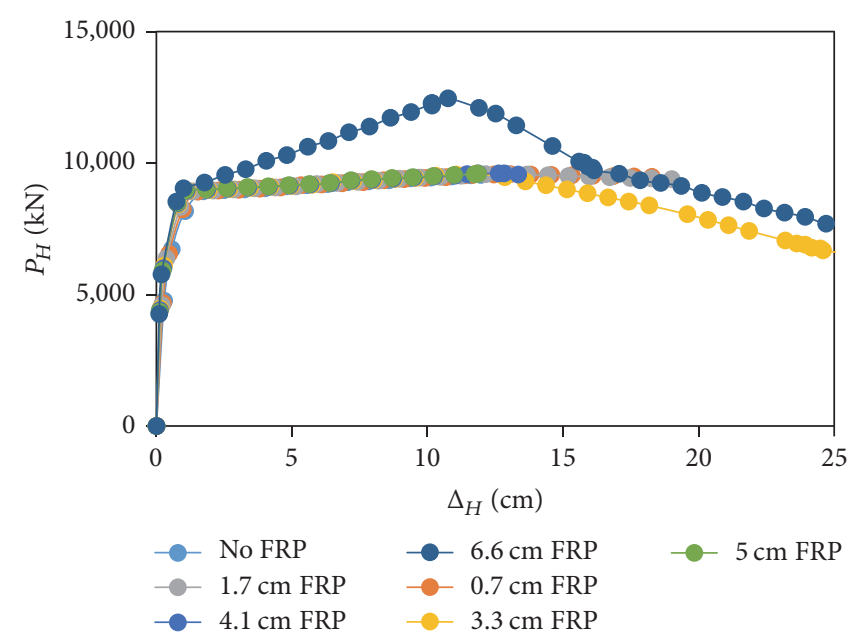

(c) Pier section: $1.5 \mathrm{~m}$ by $1.5 \mathrm{~m}$

Figure 12: Wide pier system with $W=12 \mathrm{~m}$ and $H=6 \mathrm{~m}\left(f_{c}^{\prime}=41 \mathrm{MPa}\right)$.

and postfailing stages were readily evaluated by considering nonlinear material properties and geometric nonlinearity.

(2) The stiffness of a pier system under vertical incremental loads doubled with the addition of FRP wraps with a thickness of $3.3 \mathrm{~cm}$. The ultimate strength, however, did not change significantly. Overall, the application of the FRP wraps enhances the vertical stability of a pier system due to the major improvement in the stiffness.

(3) The ultimate strength and stiffness of a pier system under incremental lateral loads increased due to the FRP wraps. Wider pier systems with an intermediate cross-sectional size of the order of $1.2 \mathrm{~m}$ by $1.2 \mathrm{~m}$ are particularly well suited to rehabilitation with FRP wraps, benefitting substantially more than slender pier systems.
(4) The design examples presented here calculated according to the ACI's recommended procedures confirmed that the strength enhancement induced by FRP application lies entirely in the compressioncontrolled region, which is a limitation of the theoretical approach. This limitation means that the effects of the tensile strength of concrete, which are usually neglected in the simplified $P-M$ interaction diagrams normally used, can easily be taken into account using the FE analysis presented in this paper.

\section{Conflicts of Interest}

The author declares that he has no conflicts of interest.

\section{Acknowledgments}

This work was supported by 2016 Georgia Southern University Senior Project, 2017 Seoul National University Invitation 


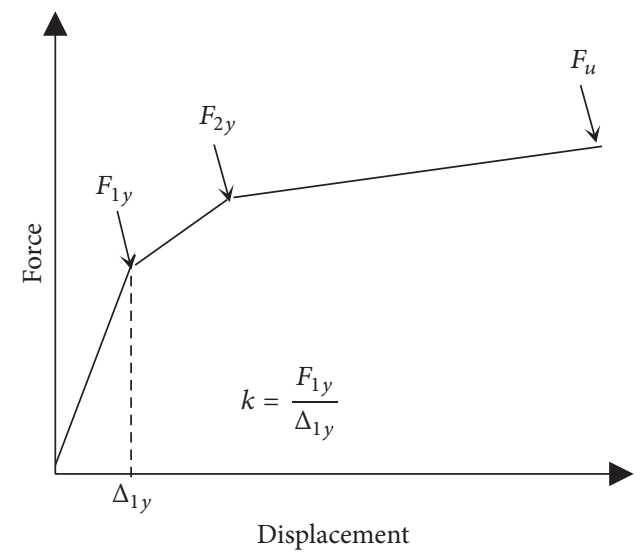

(a) Notation

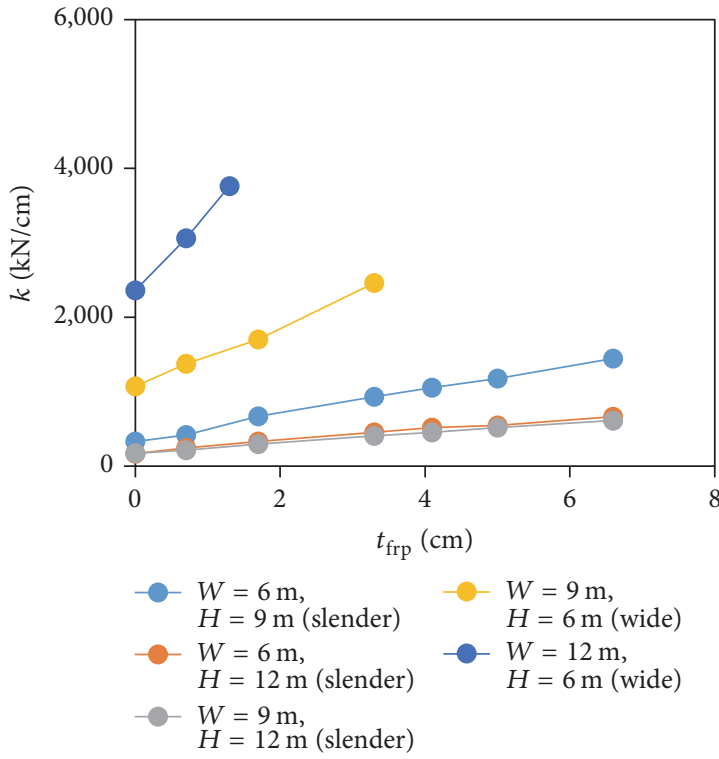

(b) Stiffness $(k)$

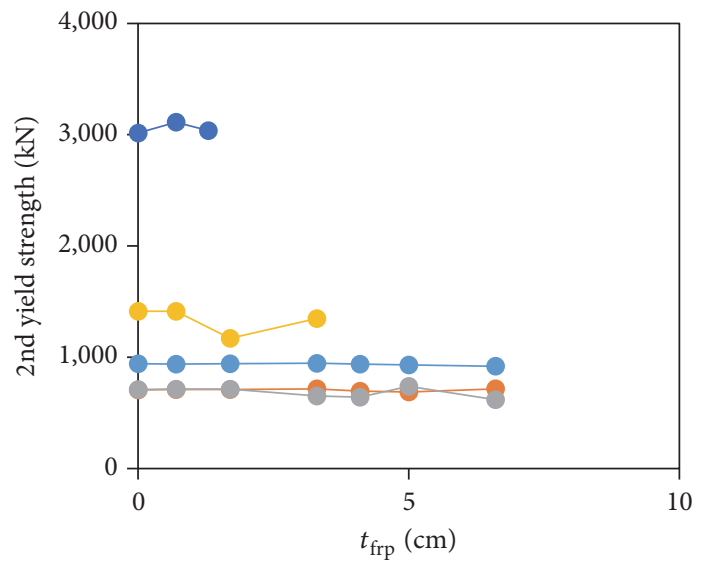

$-W=6 \mathrm{~m}$, $H=9 \mathrm{~m}$ (slender)

-C $W=6 \mathrm{~m}$, $H=12 \mathrm{~m}$ (slender)

- $W=9 \mathrm{~m}$ $H=6 \mathrm{~m}$ (wide) $W=9 \mathrm{~m}$, $H=12 \mathrm{~m}$ (slender)

(d) 2nd yield strength $\left(F_{2 y}\right)$

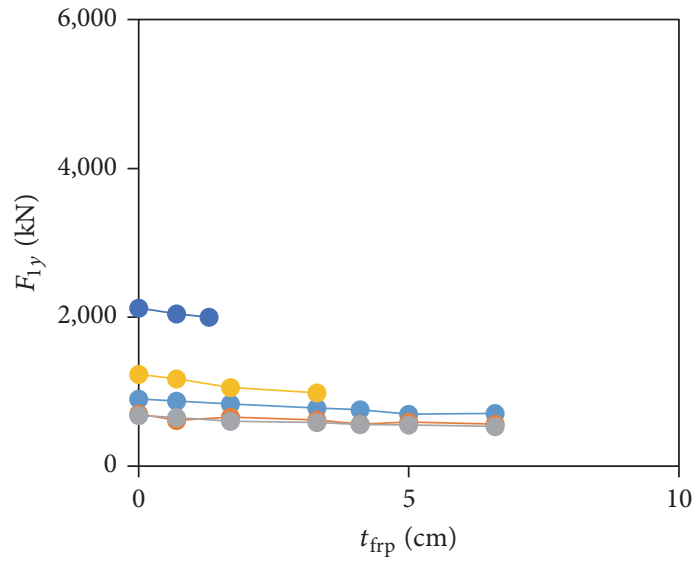

- $W=6 \mathrm{~m}, \quad-W=9 \mathrm{~m}$, $H=9 \mathrm{~m}$ (slender)

- $W=6 \mathrm{~m}$ $H=12 \mathrm{~m}$ (slender) $H=6 \mathrm{~m}$ (wide) $W=9 \mathrm{~m}$, $H=12 \mathrm{~m}$ (slender)

(c) 1st yield strength $\left(F_{1 y}\right)$

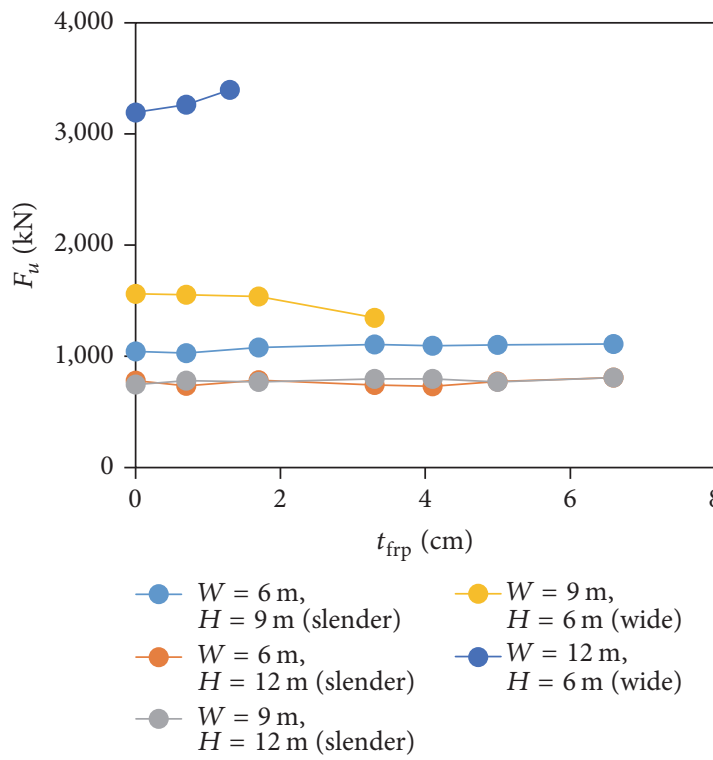

(e) Ultimate strength $\left(F_{u}\right)$

FIGURE 13: Effects of FRP thicknesses for various geometries of pier systems (pier section $=0.9 \mathrm{~m}$ by $0.9 \mathrm{~m}, t_{\text {frp }}=$ thickness of FRP wrap). 


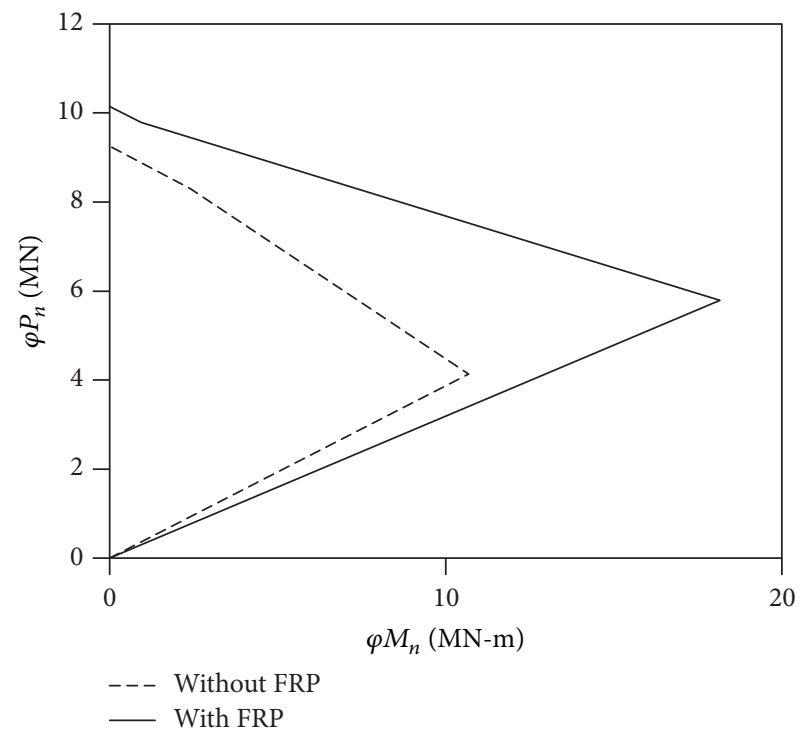

(a) Pier dimension: $0.6 \mathrm{~m}$ by $0.6 \mathrm{~m}, N_{r}=12, N_{\mathrm{frp}}=6$, and $f_{c}^{\prime}=6,500 \mathrm{psi}$

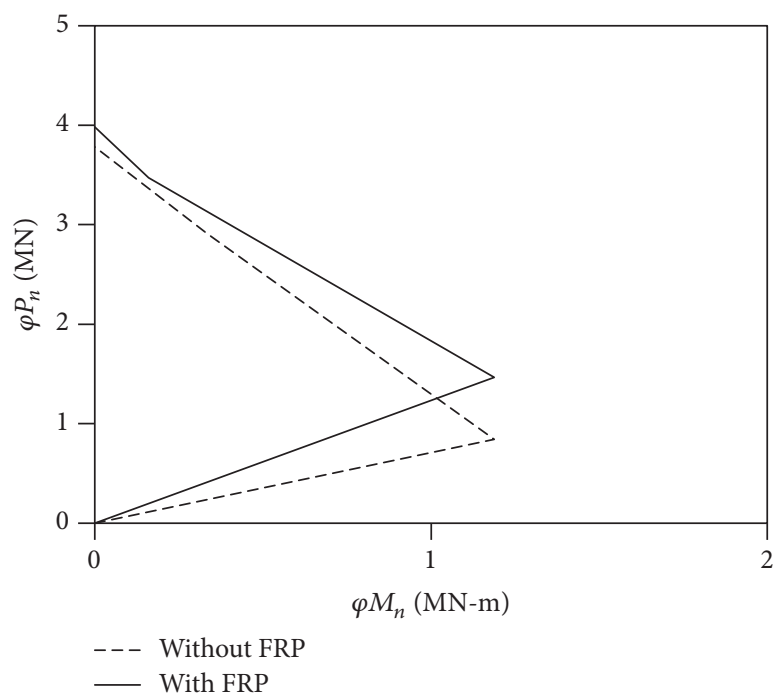

(c) Pier dimension: $0.3 \mathrm{~m}$ by $0.3 \mathrm{~m}, N_{r}=12, N_{\text {frp }}=3$, and $f_{c}^{\prime}=$ $6,500 \mathrm{psi}$

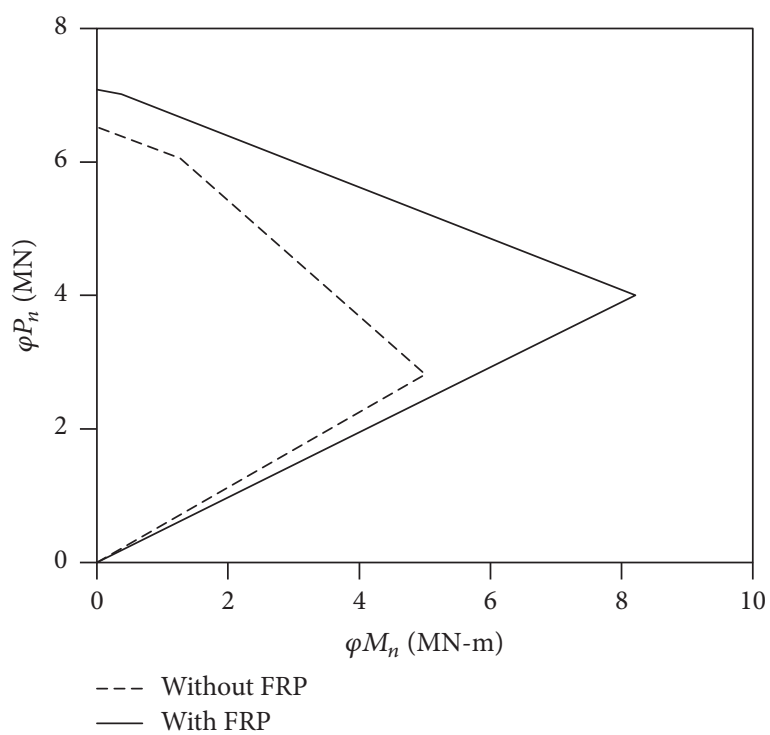

(b) Pier dimension: $0.6 \mathrm{~m}$ by $0.6 \mathrm{~m}, N_{r}=12, N_{\text {frp }}=4$, and $f_{c}^{\prime}=$ $4,000 \mathrm{psi}$

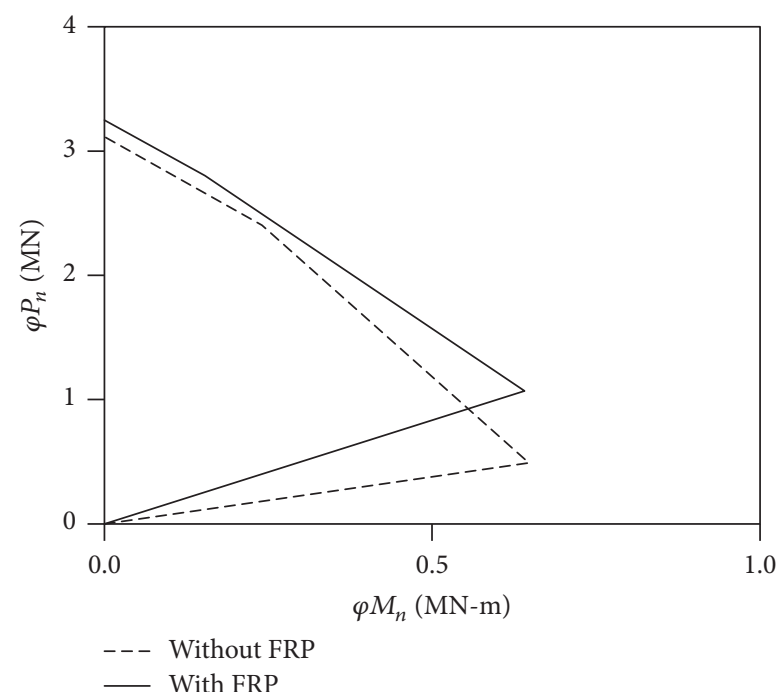

(d) Pier dimension: $0.3 \mathrm{~m}$ by $0.3 \mathrm{~m}, N_{r}=12, N_{\text {frp }}=3$, and $f_{c}^{\prime}=$ $4,000 \mathrm{psi}$

FIGURE 14: Simplified $P-M$ interaction diagrams for rectangular reinforced concrete columns $\left(N_{r}=\right.$ amount of rebar; $N_{\text {frp }}=$ number of FRP plies; and $f_{c}^{\prime}=$ compressive strength of concrete).

Program for Distinguished Scholar, and a grant funded by Ministry of Land, Infrastructure and Transport (MOLIT) of Korea Agency for Infrastructure Technology Advancement (KAIA) (17CTAP-C132633-01).

\section{References}

[1] A. Balsamo, G. P. Ludovico, A. Prota, G. Manfredi, and E. Cosenza, Composites for Structural Strengthening, Wiley Encyclopedia of Composites, 2nd edition, 2012.

[2] M. N. S. Hadi, "Behaviour of FRP strengthened concrete columns under eccentric compression loading," Composite Structures, vol. 77, no. 1, pp. 92-96, 2007.
[3] A. B. Pridmore and V. M. Karbhari, Structural Response of near Surface Mounted CFRP Strengthened Reinforced Concrete Bridge Deck Overhang, California Department of Transportation, San Diego, Calif, USA, 2008.

[4] S. E. Gunaslan and H. Karasin, "Use of FRP composite material for strengthening reinforced concrete," European Scientific Journal, vol. 10, 2014.

[5] A. K. Chauhan and N. B. Umravia, "Strengthening of Reinforced Concrete Columns Using FRP," International Journal of Global Technology Initiatives, vol. 1, no. 1, 2012.

[6] T. Alkhrdaji, "Strengthening of concrete structures using FRP composites," Structure Magazine, pp. 18-20, 2015. 
[7] ACI 440.2R-08, Guide for the Design And Construction of Externally Bonded FRP Systems for Strengthening Concrete Structures, American Concrete Institute, Detroit, Mi, USA, 2008.

[8] Structural Technologies, 2016, https://www.vsl.net/service/strengthening.

[9] CSI Reference Manual on SAP2000, Computers and Structures, Inc, Walnut Creek, Calif, USA, 2017.

[10] N. K. Shattarat, M. D. Symans, D. I. McLean, and W. F. Cofer, "Evaluation of nonlinear static analysis methods and software tools for seismic analysis of highway bridges," Engineering Structures, vol. 30, no. 5, pp. 1335-1345, 2008.

[11] N. Shatarat, M. Shehadeh, and M. Naser, "Impact of plastic hinge properties on capacity curve of reinforced concrete bridges," Advances in Materials Science and Engineering, vol. 2017, Article ID 6310321, 13 pages, 2017.

[12] S. Kulkarni and U. N. Karadi, "Nonlinear analysis of existing rc bridge using SAP 2000," Civil and Environmental Research, vol. 6, no. 12, 2014.

[13] A. J. Kappos, T. S. Pardaskeva, and A. G. Sextos, "Modal pushover analysis as a means for the seismic assessment of bridge structures," in Proceedings of the 4th European Workshop on the Seismic Behaviour of Irregular and Complex Structures, Paper no. 49, 2005.

[14] Caltrans, "Caltrans seismic design criteria," Tech. Rep. 1., California Department of Transportation, 2010.

[15] FEMA, "Prestandard and commentary for the seismic rehabilitation of buildings," Tech. Rep. FEMA 356, American Society of Civil Engineers for the Federal Emergency Management Agency, Washington, DC, USA, 2000.

[16] FHWA, "Seismic retrofitting manual for highway structures: part 1- bridges," Publication, vol. No, pp. 06-032, 2006.

[17] K. Sethy, "Application of Pushover Analysis to RC Bridges," Tech. Rep., Department of Civil Engineering, National Institute of Technology, Rourkela, India, 2011.

[18] S. Rocca, N. Galati, and A. Nanni, "Interaction diagram methodology for design of FRP-confined reinforced concrete columns," Construction and Building Materials, vol. 23, no. 4, pp. 1508-1520, 2009. 

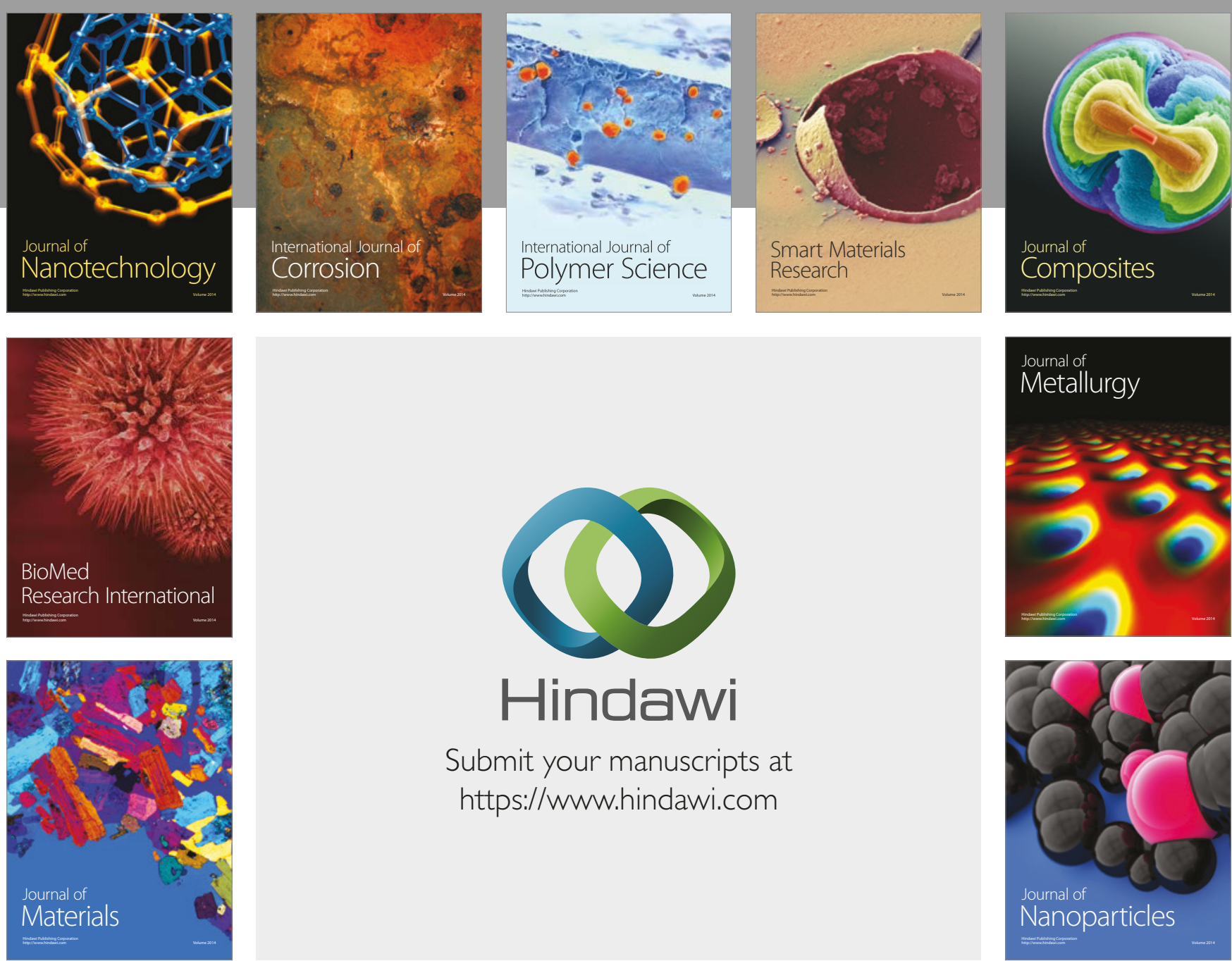

\section{Hindawi}

Submit your manuscripts at

https://www.hindawi.com
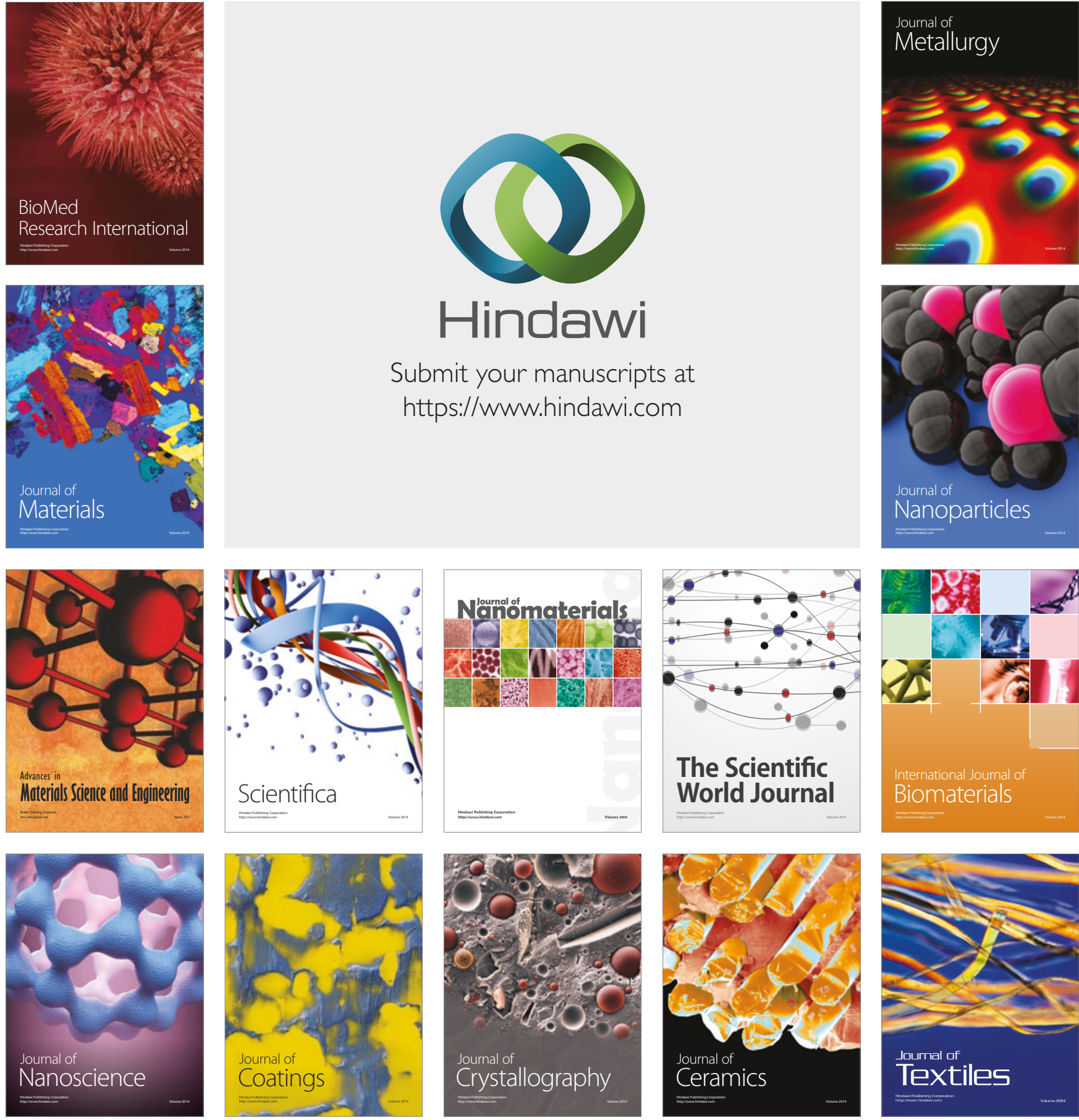

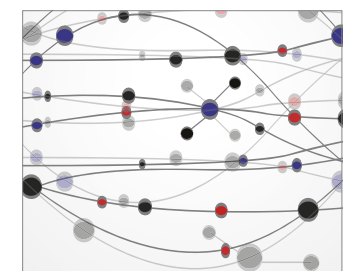

The Scientific World Journal
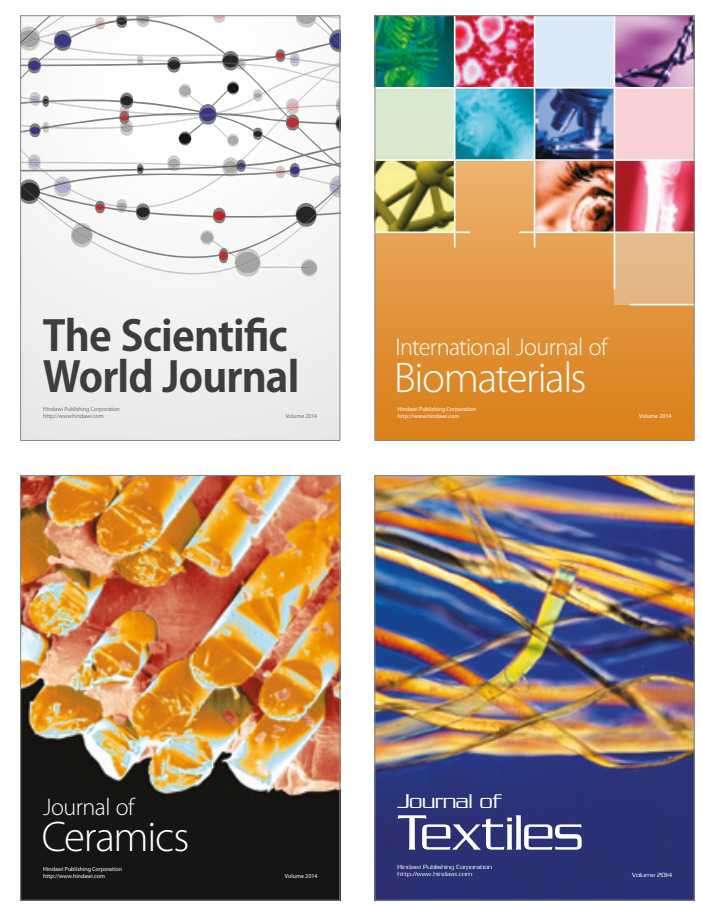